\title{
CENÁRIOS ESPECULATIVOS PÓS-PANDÊMICOS
}

\author{
a catástrofe sanitária e as redes solidárias
}

\author{
Guilherme Prege ${ }^{1}$ \\ Universidade do Estado do Rio de Janeiro (UERJ) \\ gfpreger@yahoo.com.br
}

\begin{abstract}
Resumo
Apresenta em termos genéricos três cenários econômicos e sociais para o período de pós-pandemia do coronavírus: o velho normal, o novo normal e o anômalo. O método para a construção dos cenários é o da fabulação especulativa. Observa-se que os dois primeiros cenários são variações de um mesmo paradigma e apenas o último pode ser considerado realmente uma "equivocação" do paradigma atual. O cenário anômalo, embora mais "improvável”, se configura o único realista a longo prazo. Nesse cenário estuda-se como o conceito de redes solidárias pode ser potencializado por uma reapropriação das plataformas digitais. Os conceitos de tecnologia social e economia solidária fornecem a melhor descrição de integração para um cenário anômalo. Termina com um esboço de uma proposta eficaz para a renda básica universal.
\end{abstract}

Palavras-chave: Coronavírus. Plataformas digitais. Tecnologia social. Economia solidária. Renda básica universal.

\section{SPECULATIVE POST-PANDEMIC SCENARIOS}

sanitary catastrophy and solidary networks

\begin{abstract}
This article presents in generic terms three economic and social scenarios for the post-pandemic period of coronavirus: the Old Normal, the New Normal and the Anomalous. The method for constructing the scenarios is speculative fabulation. The article notes that the first two scenarios are variations of the same paradigm and only the latter can be considered really an "equivocation" of the current paradigm. The anomalous though more "unlikely" is the only realistic long-term scenario. In this scenario, we study how the concept of Solidarity Networks can be enhanced by a reappropriation of digital platforms. The concepts of Social Technology and Solidarity Economy provide the best description of integration for an anomalous scenario. The article ends with an outline of an effective proposal for Universal Basic Income.
\end{abstract}

Keywords: Coronavirus. Digital platforms. Social technology. Solidarity economy. Universal basic income.

\footnotetext{
${ }^{1}$ Doutor em Literatura Comparada e Teoria da Literatura pela UERJ, Mestre em Eletromagnetismo Aplicado pela PUC/RJ. Atualmente, trabalha como engenheiro de FURNAS no Rio de Janeiro.
} 


\section{ARTIGO}

INOVAÇÃO

\section{O ACONTECIMENTO E A FERIDA NARCÍSICA}

Mais do que nunca, durante o período da pandemia ocasionada pela doença do novo coronavírus (Covid-19), multiplicaram-se as fabulações especulativas sobre o futuro. Essas fabulações apontam para o caráter de interrupção do acontecimento, que determina uma marca de passagem e abre um período de completa indeterminação histórica, como um vértice. A interrupção indica que certo caminho civilizatório que a humanidade trilhava em termos deterministas foi provisória ou definitivamente suspenso. $\mathrm{O}$ vértice do acontecimento surge quando as miríades de explicações e de interpretações não dão conta de situá-lo, como se ele fosse uma fonte de informação infinita. Todo acontecimento é um "delta de Dirac" informativo. A proliferação das narrativas ideológicas de justificação ou conspiratórias tentam aprisionar o acontecimento em algum enquadramento semântico, mas ele resiste a ser enquadrado. As fabulações especulativas procuram capturar esse transbordo semiótico gerado pela transgressão dos enquadramentos, para com ele figurar os mundos possíveis gerados pelo acontecimento.

Nesse sentido, a pandemia do coronavírus marca um novum, o emergir de um novo mundo que é acompanhado por seu estranhamento cognitivo, como descrito na obra do teórico da ficção científica Darko Suvin (1972). Notável é o fato de que as múltiplas narrativas e fabulações contemporâneas voltem seu foco para o campo das ciências biológicas, econômicas e médicas. Narrativas científicas tomam de assalto as mais ordinárias conversas cotidianas, ou “compartilhamentos" em mídias sociais. Tornou-se um lugar comum imaginar-se vivendo em algum roteiro de ficção científica. Essa sensação, no entanto, não deve ser entendida apenas como metáfora ou analogia. Efetivamente estamos no campo existencial das fabulações especulativas que, como demonstrou o também crítico literário Robert Scholes (1975), representam a ficção do futuro. E se, de fato, as narrativas não forem apenas discursos verbais e para além desses nos enredarem a todos em histórias e intrigas materiais? Assim, no dizer do estruturalista Algirdas Greimas (1973), em sua teoria das narrativas, não passamos de “actantes" de histórias que outros contam de nós ou que nós contamos dos outros, ou ainda mais comumente, de ambas.

Narrativas são relatos de relatos, e um acontecimento pode marcar então um ponto de encontro entre narrativas concorrentes ou divergentes. Na teoria poética aristotélica, esse ponto é uma peripécia, ou uma reviravolta, isto é, uma bifurcação. Se é bifurcação ou ponto de encontro, depende da direção de sentido que se percorre as narrativas. Se a pandemia do coronavírus é uma reviravolta é necessário, então, entender quais narrativas ela bifurca. Uma narrativa conspiratória tenta encaixar o acontecimento como um evento menor de uma intriga 
maior. Como acontecimento, no entanto, ele explode e bifurca as histórias que "vinham sendo contadas". Contar, aqui, deve ser entendido em seu duplo sentido de contar a história e calcular seus desdobramentos. A partir do acontecimento, a série causal é perdida e a contagem tornase indeterminada. As fabulações especulativas vêm então para a socorrer a imaginação antecipadora. Como diz um dos principais críticos contemporâneos das tecnologias digitais, Eric Sadin, precisamos de uma "ficção científica do cotidiano"2.

Mas o que há de efetivamente novo na pandemia não pode ser a doença em si, ou mesmo seu caráter epidêmico. Ao contrário, desde sempre a história da humanidade tem sido história de epidemias. Recentemente, a historiografia recuperou os relatos da epidemia de gripe espanhola que há exatos 100 anos matou milhões de pessoas em todo o planeta, inclusive milhares no Brasil. A memória dessa epidemia grave foi encoberta pelos dois acontecimentos históricos que ela intermediou, as assim chamadas Guerras Mundiais. Isso indica que o valor "acontecimental" depende sempre do observador. Outros historiadores lembram que a peste negra, isto é, bubônica, foi responsável por acelerar o fim da era medieval. A epidemia de varíola foi usada como arma bacteriológica na conquista das Américas levando a um extermínio das populações indígenas. A cólera representou também a morte de milhares de pessoas durante o século XIX. Esses são acontecimentos históricos que ressoam no atual momento.

Porém, ainda mais recentemente tivemos a grave epidemia da Sida, que até hoje não tem cura definida, as epidemias do ebola, ou as epidemias bem conhecidas no Brasil da dengue, da zica e da chicungunha, que estão se tornando endêmicas, como a malária em certas regiões. Essas últimas epidemias foram "regionalizadas" ideologicamente como típicas de países tropicais, Finalmente, neste mesmo século tivemos as anteriores gripes aviária e suína e a própria SARS, que tiveram consequências drásticas sobretudo no Extremo Oriente. Como defendeu em entrevista recente o teórico marxista Mike Davis, vivemos uma "era das pandemias"3, que são geradas de forma massiva pelas condições de vida produzidas pelo capitalismo neoliberal do século XXI.

O que há então de novo nesta pandemia do coronavírus, se a espécie do Homo sapiens convive desde sempre com endemias, epidemias e pandemias? Se os próprios vírus, como dizem muitos biólogos e geneticistas, tiveram uma importância fundamental na diversidade das

\footnotetext{
2 SADIN, Eric. "As tecnologias digitais têm poder de decisão em nossas vidas". Disponível em http://www.ihu.unisinos.br/601535-as-tecnologias-digitais-tem-poder-de-decisao-em-nossas-vidas-entrevista-c om-eric-sadin. Acesso em: 06 ago. 2020.

3 DAVIS, Mike. "Não vivemos em uma pandemia, mas em uma era de pandemias". Entrevista com Mike Davis. Entrevistadora: Josefina L. Martínez. IHU Notícias, São Leopoldo, 2020. Disponível em: http://www.ihu.unisi nos.br/78-noticias/601135-nao-vivemos-em-uma-pandemia-mas-em-uma-era-de-pandemias-entrevista-com-m ike-davis. Acesso em: 22 jul. 2020.
} 
espécies? Um vírus é uma cadeia de aminoácidos que está na exata fronteira entre o vivo e não vivo. Um vírus só pode se reproduzir se ele se "acoplar" a um organismo qualquer que lhe permita replicar-se. Daí uma de suas lições básicas: vida é reprodução, uma surpreendente confirmação da teoria psicanalítica desde Freud, que é a de que a reprodução da vida sobredetermina sua conservação. O vírus é uma demonstração cabal desse domínio primário da reprodução sobre a conservação. No entanto, devemos manter o ceticismo em classificar como a novidade do coronavírus sua incrível capacidade de reprodução e proliferação, ou seja, sua "virulência". Seria uma conclusão tautológica: o vírus é excepcional pela sua capacidade de viralização. Tampouco nova é sua capacidade de acoplagem, pois é próprio de todo vírus tornar organismos como seus hospedeiros.

$\mathrm{O}$ que se revelou efetivamente novo nesta pandemia foi a maneira como rapidamente o vírus, um elemento "natural", conseguiu penetrar a blindagem que supostamente separava a economia humana artificial da ecologia "externa" da natureza. A suspensão da atividade econômica foi sentida como uma "intrusão viral" e imediatamente a economia globalizada percebeu que tinha um "corpo" que poderia adoecer. Ou seja, descobriu sua organicidade quase sempre relegada ao esquecimento. O vírus provocou uma "ferida" nesse corpo recémdescoberto. Ou, ainda melhor, o corpo só foi redescoberto por se reconhecer "ferido". Essa ferida foi de ordem sobretudo narcísica, para lembrar do famoso dito de Freud a respeito do surgimento da psicanálise (comparando-a com a fenomenologia de Kant e a teoria darwinista). A humanidade se achava protegida em sua "couraça" tecnológica, imunizada contra novos surtos epidêmicos, que estariam reservados apenas às regiões "atrasadas" do planeta. No entanto, o que aconteceu foi que o vírus penetrou por certa "falha metabólica"4 da esfera econômica e tecnológica que considera as fronteiras naturais como externalidades, isto é, como estando do "lado de fora" do circuito econômico.

Daí que o isolamento provocado por essa doença seja sentido de forma generalizada como um "padecimento" e um sentimento de melancolia. A ilusão da imunidade tecnológica foi desfeita e a pandemia do coronavírus revela o corpo social adoecido. O isolamento, tido como a prática mais "racional" diante da propagação virótica, na verdade é uma simples aplicação do princípio de precaução em relação a um vírus cujo comportamento é ainda desconhecido. A necessidade do isolamento foi sentida socialmente como uma derrota melancólica. Então, se a pandemia não representa realmente algo de novo, pois não há novidade numa virose, esse sentimento melancólico gerado pela interrupção forçada das atividades, bem

\footnotetext{
4 Referência ao tema do "Metabolic Rift" nos Esboços (Grundrisse) de Marx.
} 
como a histérica necessidade de se voltar logo ao "normal", revelam que o acontecimento foi antes psíquico. No dizer coloquial, o vírus tocou uma ferida que, no entanto, já parecia aberta, mas que não era sentida pois não se percebia o corpo social que poderia adoecer economicamente. No dizer do antropólogo Bruno Latour, a pandemia do coronavírus é um verdadeiro "ensaio geral” da crise (ou da catástrofe) ecológica que se avizinha, ou na qual talvez já estejamos 5 . É, em seus próprios termos, um "aterramento"6.

Como já abordado por muitos, o que há de surpreendente nessa pandemia foi o perfeito casamento entre o vírus biológico e as cadeias produtivas globalizadas. Como demonstram vários estudos anteriores à emergência da doença do coronavírus, a produção alimentícia de carne vermelha em enormes fazendas, aliadas à devastação ambiental produzida pelas pastagens ou pela especulação imobiliária, ou ainda pela economia extrativista, formam um criadouro propício ao surgimento e à rápida proliferação de vírus ${ }^{7}$. O Covid-19 se globalizou na aceleração da cadeia produtiva neoliberal global. Seu fluxo, do Extremo Oriente ao Ocidente, perseguiu justamente o fluxo da circulação de mercadorias e de seu consumo, da divisão da economia onde o Oriente produz e o Ocidente consome. Assim, a pandemia não foi realmente o acontecimento, mas sim a perfeição com que o vírus se acoplou e infectou as cadeias de produção, circulação e consumo, e acompanhou o fluxo transnacional das viagens internacionais, seja de negócios ou de turismo. Essas cadeias que se acreditavam imunes revelaram-se mais frágeis do que se imaginava. Descobriram que possuem um corpo e que este é uma reunião de outros corpos que, como organismos biológicos, adoecem. A pandemia causou sem dúvida um padecimento social, pois quem tem corpo padece.

Ainda assim, não foi esse de fato o acontecimento. Se o vírus contaminou a ferida narcísica, ele só se tornou realmente acontecimento enquanto sintoma, isto é, enquanto evento semiótico ou semiotizado. E isso também aconteceu com velocidade impressionante. Já era comum utilizar a metáfora do vírus para conotar um processo informativo acelerado, afirmar que certa informação "viralizou", isto é, se disseminou pelas redes digitais. O acoplamento do vírus biológico e do vírus informacional foi ainda mais completo com o acoplamento econômico, a ponto de figurar enquanto uma infodemia, isto é, uma inflação do uso dos meios digitais. Na verdade, a pandemia acelerou os processos de digitalização comerciais e financeiros

\footnotetext{
5 LATOUR, Bruno. A crise sanitária incita a nos preparar para as mudanças climáticas. IHU Notícias, São Leopoldo, 27 mar. 2020. Disponível em: http://www.ihu.unisinos.br/78-noticias/597499-a-crise-sanitariaincita-a-nos-preparar-para-as-mudancas-climaticas-artigo-de-bruno-latour. Acesso em: 23 jul. 2020.

6 LATOUR, Bruno. Onde Aterrar. Rio de Janeiro: Bazar do Tempo, 2020.

7 WALLACE, Rob. Big Farms Make Big Flu: Dispatches on Infectious Disease, Agribusiness, and the Nature of Science. New York: Monthly Review Press, 2016.
} 


\section{ARTIGO}

INOVAÇÃo

que já vinham ocorrendo antes. Isoladas em suas casas, as pessoas recorreram de forma massiva às redes digitais para se comunicar e sobretudo para trabalhar. O teletrabalho rapidamente foi implantado na maioria das empresas, onde antes se exigia com rigor industrial o infame uso do ponto de horário. A rápida normalização do teletrabalho provou que a flexibilidade de horários já era uma prática acessível à maioria das empresas. O distanciamento social também acarretou um grande uso de aplicativos para comunicação à distância, gerando as famosas "lives", videoconferências que a partir do Ensino à Distância $(\mathrm{EaD})$ tiveram seu uso expandido para todo tipo de reunião, de trabalho, lazer, trocas afetivas, debates políticos, etc.

Então, de forma ainda mais intensa, a prática do distanciamento social fortaleceu desmedidamente a assim chamada "economia de aplicativo", ou de "plataforma", na qual o oferecimento de produtos ou serviços por demanda se tornou um ramo predominante. Desse modo, ganhou visibilidade a antes negligenciada categoria dos entregadores, que se tornaram os nômades da nova configuração social, cruzando as ruas da cidade entre as residências de classe média. A mobilidade desses trabalhadores precarizados e a relativa fixidez da classe média, que podia usufruir do teletrabalho, bem como de conexões digitais de maior capacidade, foram dois dos índices mais acentuados das divisões de classe do capitalismo contemporâneo.

É possível então dizer que a intrusão do vírus biológico foi metabolizada através de sua digitalização. Semioticamente o coronavírus se transformou num ícone digital pronto para ser "memetizado", isto é, copiado e repassado. O vírus basicamente é, ele mesmo, um código orgânico inscrito numa cadeia de aminoácidos. Esse código é ativado através de um acoplamento aleatório em um célula viva, que passa a ser sua hospedeira. $\mathrm{O}$ vírus basicamente é um parasita, mas essa parasitagem não deixa de ser informativa ${ }^{8}$. $\mathrm{O}$ êxito do vírus em seu contágio revela que encontrou na parasitagem um ecossistema propício, adequado. Esse êxito revela a própria organização parasitária da economia digital, tanto financeira, quanto comercial, através das plataformas de aplicativos. Enquanto ruído informacional parasitário, o vírus "equivocou"9 a economia global, mais do que a interrompeu. Ele acelerou certos processos enquanto atrasou otros, e mexeu com a sincronia da cadeia, gerando todos os tipos de defasagens temporais. Mas é preciso dizer que os sistemas neoliberais já se encontravam em franca instabilidade; daí talvez se entenda as condições de criticidade do sistema que permitiram o surgimento desses efeitos propagantes à alta velocidade. $\mathrm{O}$ vírus foi então um gatilho, um

\footnotetext{
8 Sobre a parasitagem enquanto fenômeno informacional, a referência é a obra de Michel Serres, Le parasite (1980). Cf. BROWN, Steven. Em louvor ao parasita: a teoria organizacional mestiça de Michel Serres. Informática na educação, Porto Alegre, v. 16, n. 1, p. 83-100, jan./jul. 2013. Disponível em https://seer.ufrgs.b r/InfEducTeoriaPratica/article/view/36928/25942. Acesso em: 23 jul. 2020.

9 Aqui me refiro ao conceito informacional de Claude Shannon de "equivocação" que discutirei mais adiante.
} 
disparo entre as tensões que já estavam pressionando todas as fronteiras integradas do sistema global da economia. Todo acontecimento é uma ressonância entre pelo menos dois eventos, isto é, uma superposição entre duas oscilações que interferem entre si, de maneira construtiva ou destrutiva.

\section{TRÊS CENÁRIOS ESPECULATIVOS}

Proponho aqui um jogo de fabulação especulativa que consiste em descrever três cenários para a pós-pandemia. O termo cenário pode ser entendido à maneira da língua francesa como sinonímia de roteiro, uma sequência de cenas montada por meio de uma narrativa. $\mathrm{O}$ acontecimento será assim um momento de bifurcação, uma peripécia ou reviravolta narrativa. Denomino esses três cenários de velho normal, novo normal e anômalo. Eles compõem um espectro completo de situações oraculares do futuro. Venha o que vier, o evento seguirá um desses três roteiros. Por isso, é também necessário entender que cada narrativa é um caminho semiótico, uma via. Há três vias possíveis de desdobramentos para a pós-pandemia.

No entanto, os cenários não devem ser compreendidos como mutuamente excludentes. Não é necessária uma escolha unitária entre três possibilidades. Aqui devemos agir conforme o princípio da indeterminação da mecânica quântica: só podemos falar sobre suas probabilidades, não sobre suas determinações. Enquanto aquelas não se desdobram, o que há é sempre uma superposição de estados. Podemos associar probabilidades de seguimento a cada uma das vias. Pretendo então descrever, especulativamente, cada um dos cenários.

O velho normal é a crença de que a pandemia é apenas uma interrupção passageira na via do desenvolvimento técnico-econômico global, aquilo que abstratamente vem sendo denominado de globalização neoliberal. É a crença no velho normal que legitima o dito de que a doença do coronavírus não passa de uma "gripezinha"10. O velho normal é a negação do acontecimento. Por isso, os três cenários não são exatamente uma "trifurcação", pois para o velho normal não há desvio, talvez apenas “tropeço”. A lógica desse cenário é menos trivial do que parece a priori. O velho normal significa que a hegemonia neoliberal é consistente e durável e conseguirá "metabolizar" completamente a pandemia. Então, a doença é apenas uma pertubação, mas tenderá, assim como a gripe espanhola, a ser "absorvida" e a rigor esquecida. O que é essa hegemonia? O neoliberalismo seria mais do que uma simples ideologia, na qual a economia financeira sobredetermina os demais setores da economia, sendo antes um novo

${ }^{10}$ Referência ao pronunciamento em cadeia nacional de televisão do Presidente brasileiro Jair Bolsonaro em 20 de março de 2020. 
INOVAÇÃo

enquadramento "epocal" do entendimento do humano, a formação de um novo modo de subjetivação, o homo economicus, isto é, um tipo de subjetividade que mimetiza um modelo empresarial em que todas as decisões vivenciais passam a ser ordenadas por critérios individuais de custo-benefício (DARDOT; LAVAL, 2016).

Enfim, o neoliberalismo é um novo modelo de regulação social, compreendendo a regulação no sentido de controle do sistema social amplamente entendido. Esse modelo incorpora a lógica binária dos meios digitais a partir de uma crescente "automatização" do social por meio de sua "governamentalidade algorítimica" (ROUVROY; BERNS, 2015). Essa nova "soberania algorítmica" é uma transferência das capacidades políticas deliberativas para a decisão através de programas. A regulação neoliberal é acompanhada, por outro lado, pela desregulamentação trabalhista, pela informalização e precarização do trabalho, pelo surgimento de um "precariado global". Este precariado, informalizado, sem direitos trabalhistas e sem organização sindical tradicional, representa uma classe trabalhadora fragmentada e incapaz de se opor de maneira organizada ao avanço do capital sobre as relações sociais, correspondendo a uma nova configuração da luta de classes. Muitas vezes, essa classe informalizada tende a ser a base política dos novos populismos autoritários globais ${ }^{11}$.

Como rejeição ao acontecimento, o velho normal é sobretudo negacionista. Negacionista da gravidade da epidemia, bem como das medidas definidas pela ciência para enfrentá-la. Mas esse negacionismo, que foi adotado prioritariamente como paradigma dos populismos de direita, tem algo de equívoco ou de francamente hipócrita. Nesses movimentos, em especial nos Estados Unidos com o presidente Trump e no Brasil, com seu vassalo Bolsonaro, há algo como um "negacionismo fake", que é um culto da ambiguidade entre a simples rejeição às prescrições de base científica e um menosprezo consciente às suas possíveis consequências. O retorno mais rápido ao funcionamento normalizado da economia parece ser a diretriz prioritária e a pandemia é tomada apenas como um "obstáculo" a esse retorno. Esses movimentos trazem de volta o conceito neodarwinista de "imunidade de rebanho", a ideia de que, seguindo seu curso normal, a pandemia será detida pela imunidade social. Mas não apenas há dúvidas quanto à eficácia desse método, como também quanto ao percentual necessário de espalhamento infeccioso para que se atinja a imunidade esperada: alguns dizem que em torno de $70 \%$ da população teria de ser infectada. A consequência lógica da aplicação desse conceito é que para uma população em torno de 200 milhões de habitantes como a brasileira e uma taxa

\footnotetext{
${ }^{11}$ Para uma tipologia do precariado e dos novos desafios de lutas, STANDING, Guy. O precariado e a luta de classes. Revista crítica de ciências sociais, Coimbra, n. 103, p. 9-24, 2014. Disponível em: https://journals.ope nedition.org/rccs/5521. Acesso em: 03 ago. 2020. Standing é o sociólogo que cunhou o termo precariado.
} 
de óbitos em torno de 3\% (média global), o número total de mortes superaria a casa de 7 milhões de pessoas num país como o Brasil. A imunidade de rebanho é uma espécie de laissez-faire epidemológico, a liberdade de contaminação do vírus semelhando-se à liberdade do fluxo de capitais pregada pelo neoliberalismo ${ }^{12}$.

Para se entender melhor a viabilidade desse cenário é preciso contrastá-lo com a do novo normal. Essa é, aliás uma expressão que "pegou", isto é, que teve uma aceitação generalizada, o que torna esse cenário o mais "visível" entre os três. O novo normal é o velho normal, porém admitindo-se um desvio de certas práticas e uma adoção de outras. O novo normal aceita que teremos um período de duração indefinida no qual se tornarão práticas usuais a adoção de máscaras, a redução de aglomerações, a higienização generalizada dos ambientes, das roupas e dos alimentos, através de álcool gel e desinfetantes e o uso intensivo das tecnologias da informação substituindo práticas presenciais, sobretudo no trabalho, na educação e no lazer. O novo normal reconhece na pandemia um evento de monta, que obriga as sociedades a se adaptarem a ele.

Sua principal diferença para o velho normal vem a ser o incremento acelerado da "datificação" da economia, inclusive com a digitalização acentuada das moedas. A principal expressão política desse novo paradigma (ou desse paradigma mutante) é o assim chamado "Screen New Deal" proposto pelo governador de Nova Iorque Andrew Cuomo. Ao contrário dos líderes negacionistas, Cuomo, que enfrentou em seu Estado o epicentro global de disseminação da epidemia, se mostrou um defensor das medidas de isolamento e distanciamento social. No entanto, ele anunciou, junto com o CEO da Google, Eric Schmidt, um audacioso plano de digitalização dos serviços e de adoção de home office, para trabalho e para lazer, turbinado pela adoção massiva de tecnologias de banda larga de infraestrutura $5 \mathrm{G}^{13}$. As novas tecnologias digitais permitiriam assim um confortável período de isolamento à espera de uma vacina definitiva, com o acesso a trabalho e serviços mediado pelas plataformas. $\mathrm{O}$ que esse cenário esconde é que o acesso das classe médias aos serviços digitalizados seria mediado efetivamente por um intenso "trabalho analógico" de uma multidão de trabalhadores precarizados em atividades de produção e de circulação, expostos aos perigos da contaminação (e da morte), sendo que os corpos desses trabalhadores forneceriam a infraestrutura material ao

\footnotetext{
12 Essa política do "deixar morrer" vem sendo chamada de necropolítica, conceito do filósofo Achille Mbembe (2020), que discuto logo a seguir. Veja também MBEMBE, Achille. Necropolítica. Arte \& ensaios, Rio de Janeiro, n. 32, p. 122-151, 2016. Disponível em: https://revistas.ufrj.br/index.php/ae/article/view/8993. Acesso em: 03 ago. 2020.

${ }^{13}$ KLEIN, Naomi. Screen New Deal. The Intercept, New York, 8 May 2020. Disponível em: https://theintercept.com/2020/05/08/andrew-cuomo-eric-schmidt-coronavirus-tech-shock-doctrine/. Acesso em: 27 jul. 2020.
} 
mundo virtualizado do trabalho e do consumo digital de classe média, supostamente sedentária em seus home offices.

Essa diferença entre trabalhadores informais nomadizados e consumidores informatizados sedentários é a forma da luta de classes do Novo Normal. No seio das classes dominantes, o novo normal abriga uma disputa pela hegemonia económica, seja na economia política tecnológica, seja na geopolítica. Na economia política, é uma disputa pelo "cume" da pirâmide de acumulação de capital, entre o setor financeiro e as empresas de "capitalismo de plataforma". Na geopolítica, o novo normal representa um novo desdobramento da Guerra Híbrida e da disputa comercial entre EUA e China pela liderança na produção da tecnologia $5 \mathrm{G}$, disputa que já vinha sendo travada bem antes da pandemia ${ }^{14}$.

O contraste entre o novo normal e o velho normal revelou-se de forma equívoca nas polêmicas intelectuais que marcaram a verdadeira inflação de leituras do significado da epidemia. Importantes filósofos, inegavelmente associados à esquerda política, como Alain Badiou $^{15}$ e Jacques Rancière ${ }^{16}$ foram bastante céticos em relação ao caráter "acontecimental" da pandemia e parecem exemplificar uma resposta de "esquerda" do velho normal. Do lado do novo normal a reação mais estridente foi a do importante filósofo italiano Giorgio Agamben. Agamben viu nas medidas restritivas de isolamento na Itália, no exato momento em que este país se tornava o epicentro global da pandemia em número de casos e mortes, uma confirmação de sua tese de que as sociedades liberais do Ocidente são regidas por um "estado de exceção médico-sanitário". Agamben observou que o veto para que parentes visitassem seus entes queridos enfermos (muitas vezes idosos) nos hospitais e não pudessem testemunhar os funerais dos falecidos era uma situação historicamente impensável desde o mito de Antígona. A nova biopolítica que a situação contemplava era uma redução do bios, isto é, da vida, ao simples estado de saúde corporal, isto é, a "vida nua" (zoo). Agamben chegou mesmo a criticar duramente o Papa Francisco pela missa isolada e vazia realizada na Praça de São Pedro, num dos momentos mais icônicos de todo este período:

A Igreja, sob um Papa que se chama Francisco, esqueceu que Francisco abraçava os leprosos. Esqueceu que uma das obras da misericórdia é a de visitar os enfermos.

${ }^{14}$ ESCOBAR, Pepe. China locked in hybrid war with US. Asia Times, Hong Long, 17 mar. 2020. Disponível em: https://asiatimes.com/2020/03/china-locked-in-hybrid-war-with-us/. Acesso em: 27 jul. 2020.

15 BADIOU, Alain. Sobre a situação epidêmica. Blog da Boitempo, São Paulo, 08 abr. 2020. Disponível em: https://blogdaboitempo.com.br/2020/04/08/badiou-sobre-a-situacao-epidemica/ . Acesso em: 27 jul. 2020.

${ }^{16}$ RANCIÈRE, Jacques. Uma boa oportunidade? São Paulo: N-1 Edições, 2020. Disponível em: https://n1edicoes.org/039-1. Acesso em: 27 jul. 2020. 
Esqueceu que os mártires ensinam que é necessário estar disposto a sacrificar a vida em vez da fé, e que renunciar ao próximo significa renunciar à fé17

Outro tipo de reação foi a rejeição à possibilidade de um novo "totalitarismo digital" a partir das experiências de controle de mobilidade no extremo asiático, notadamente na China, na Coreia e em Cingapura, onde as restrições de lockdown (proibição de circulação) vieram acompanhadas de um intenso rastreio viabilizado pela comunicação digital. A partir de aplicativos que fornecem dados de geolocalização, os Estados conseguem detectar a presença de pessoas infectadas, sendo possível restringir a circulação da população a partir de enquadramentos reticulares dos mapas digitais. A rejeição a esse cenário ocorreu nos casos dos conhecidos intelectuais como o coreano Byung-Chul Han ${ }^{18}$ e o israelense Yuval Harari. Este último vê claramente como a pandemia impulsiona as soluções de vigilância digital e automação do trabalho (pois as máquinas não ficam doentes), porém defende que o cenário futuro será marcado fundamentalmente ou pelo fechamento nacionalista das fronteiras (o isolamento como estratégia nacionalista) ou por uma "solidariedade global"19.

No entanto, o receio dos intelectuais dos centros globais a respeito do "totalitarismo de exceção", viabilizado tanto como política de Estado quanto por tecnologias de vigilância, ou seja, por uma "tecnopolítica da vigilância" (BRUNO et al., 2018), contrasta fortemente com a posição de negacionismo de muitos líderes populistas de direita, cujo caso mais clamoroso é o do presidente brasileiro Jair Bolsonaro. Este último adotou como política de Estado frustar as medidas de isolamento social e forçar as classes populares a saírem de casa o mais rapidamente possível, pois a "economia não pode parar". Assim, enquanto as nações centrais do capitalismo avançado defendiam uma biopolítica do isolamento, na periferia capitalista adotava-se a "necropolítica" (MBEMBE, 2020), de cunho eugenista e neodarwinista do "morra quem tem que morrer". Na verdade, a dicotomia biopolítica/necropolítica pode ser perfeitamente

${ }^{17}$ AGAMBEN, Giorgio. Uma pergunta. Artigo de Giorgio Agamben. IHU notícias, São Leopoldo, 18 abr. 2020. Disponível em: http://www.ihu.unisinos.br/598071-uma-pergunta-artigo-de-giorgio-agamben. Acesso em: 27 jul. 2020. A editora Boitempo lançou o e-book Reflexões sobre a peste (São Paulo, 2020) contendo o texto. As polêmicas posições do filósofo italiano geraram inúmeras reações e respostas à sua "pergunta". Uma delas é a de Jean-Luc Nancy, filósofo da mesma envergadura e amigo de Agamben, Exceção viral (São Paulo, 2020. Disponível em https://n-1edicoes.org/065. Acesso em: 27 jul. 2020).

${ }^{18}$ HAN, Byung-Chul. O coronavírus de hoje e o mundo de amanhã, segundo o filósofo Byung-Chul Han. El País Brasil, São Paulo, 22 mar. 2020. Disponível em: https://brasil.elpais.com/ideas/2020-03-22/o-coronavirus-dehoje-e-o-mundo-de-amanha-segundo-o-filosofo-byung-chul-han.html. Acesso em: 28 jul. 2020. Han distingue entre as respostas orientais e ocidentais, supondo que no extremo-oriente um difuso "confucionismo" favoreça respostas de vigilância social em detrimento das liberdades individuais. Ele alerta para o perigo de que "Uma biopolítica digital que acompanha a psicopolítica digital que controla ativamente as pessoas". Acredita que a resposta europeia de isolamento, embora menos eficaz, no entanto, preserva a democracia.

${ }^{19}$ HARARI, Yuval Noah. O mundo depois do coronavírus. IHU notícias, São Leopoldo, 26 mar. 2020. Disponível em: http://www.ihu.unisinos.br/78-noticias/597469-o-mundo-depois-do-coronavirus-artigo-de-yuval-noahharari. Acesso em: 28 jul. 2020. 
transposta para as distinções Norte/Sul global ou centro/periferia. Vários autores chamaram atenção para o aspecto "imperialista" ou "eurocêntrico" das reações dos intelectuais globais e, ao mesmo tempo, para a relação de contiguidade entre bio e necropolítica. O “deixar viver" das populações mais ricas deve ser complementado pelo "deixar morrer" dos povos pobres ${ }^{20}$. Ao mesmo tempo é possível entender que a necropolítica é totalmente compatível com a lógica da ordem espontânea dos mercados preconizada por Friedrich Hayek, considerada como a única maneira legítima de regular a economia. A imunidade de rebanho é uma espécie de "ordem espontânea" 21 da imunização coletiva que, no entanto, é completamente cega às consequências na vida concreta das populações.

O contraste entre velho e novo normal parece antes significar um complemento do que realmente duas vias diferentes de continuidade. Se o velho normal ignora o acontecimento da pandemia, o novo normal parece ser antes um contorno. Essas duas vias discursivas (narrativas) ocultam uma cumplicidade e uma co-implicação. Quem mais repete a versão do novo normal também acredita que as duas vias irão se juntar mais à frente, daqui a alguns anos. Se o velho normal é um atalho, o novo normal acelera algumas mudanças que já estavam no horizonte do capitalismo neoliberal, que são sua inevitável digitalização e a progressiva substituição do trabalho por automação, com a precarização do trabalho restante que, para se tornar lucrativo, deverá ser hiperexplorado. A completude da transição digital do capitalismo para sua versão neoliberal algoritmizada é uma "narrativa latente" que os cenários descritos escondem.

Por isso é possível acreditar que a via anômala é realmente o único desvio verdadeiro. Essa via não precisa ser unitária. Se ela faz jus ao acontecimento como uma bifurcação da via do grande (velho + novo) normal, o anômalo deve assumir a própria verdade dessa bifurcação, considerando outras possíveis bifurcações, gerando assim uma multiplicidade de vias. Essas vias podem ser divergências a princípio, mas convergências posteriores, formando algo como

\footnotetext{
${ }^{20}$ Seguiram essa linha de crítica que relaciona a biopolítica das economias centrais à necropolítica das economias pobres as várias intervenções do sociólogo português Boaventura Sousa dos Santos, notadamente no artigo $A$ trágica transparência do vírus (Sul21, Porto Alegre, 11 abr. 2020. Disponível em: https://www.sul21.com.br/opiniaopublica/2020/04/a-tragica-transparencia-do-virus-por-boaventura-de-sousasantos/) e O coronavírus, nosso contemporâneo (Sul21, Porto Alegre, 17 maio 2020. Disponível em: https://www.sul21.com.br/opiniaopublica/2020/05/o-coronavirus-nosso-contemporaneo-por-boaventura-desousa-santos). A editora Boitempo lançou o e-book A cruel pedagogia do vírus (São Paulo, 2020) contendo as reflexões do sociólogo português. No contexto indiano, a intervenção A comunidade dos abandonados: uma resposta a Agamben e Nancy (disponível em https://n-1edicoes.org/085) dos intelectuais Divya Dwevedi e Shaj Mohan (acesso em 28 jul. 2020) também observou o mesmo problema. No contexto brasileiro, vários estudiosos também fizeram objeções sobre a posição de intelectuais europeus, p. ex., FRATESCHI, Yara. Agamben sendo Agamben: o filósofo e a invenção da pandemia. Blog da Boitempo, São Paulo, 12 maio 2020. Disponível em https://blogdaboitempo.com.br/2020/05/12/agamben-sendo-agamben-o-filosofo-e-a-invencao-da-pandemia/. Acesso em: 29 jul. 2020.

${ }^{21} \mathrm{O}$ conceito é de Hayek.
} 
uma rede ou uma malha de vias. A função de desvio, que provoca a bifurcação, pode ser pensada antes como uma equivocação do normal, no sentido que Claude Shannon, o formulador da teoria da informação, deu a ela (equivocation). A equivocação acontece sempre que uma mensagem emitida chega a seu receptor portando junto o "ruído" do meio, de modo que a mensagem final é a informação emitida mais esse ruído (SHANNON, 1948). Desse ponto de vista, a pandemia virótica foi o ruído que equivocou as vias normais (suas narrativas), criando as oportunidades de outras narrativas.

Já o conceito de anomalia vem, obviamente, da sociologia da ciência de Thomas Kuhn (1970). Anomalia significa a descoberta de um "ponto fora da curva", um resultado que resiste a ser integrado a algum paradigma hegemônico que conduza a pesquisa científica, isto é, a "cosmovisão" que orienta a formulação de teorias e de seus sistemas ${ }^{22}$. Ou seja, a anomalia, em seu caráter inassimilável, representa a resistência a uma "renormalização" pelo paradigma através de algum "ajuste" ou acomodação. O viés anômalo é, portanto, aquela via que trabalha com a irredutibilidade do acontecimento da pandemia, o fato de que a equivocação gerada por seu evento é capaz de produzir um desvio crescentemente divergente em relação à normalidade do sistema capitalista. Assim, por exemplo, quando mesmo a maioria das projeções dos economistas ortodoxos aponta para um PIB global negativo (recessão) que fatalmente terá lugar em 2020, um fato que não ocorre desde $1961^{23}$, e que corresponde a um decrescimento forçado, o viés do grande normal apenas pensa na recuperação econômica em alguns anos. Já a via anômala vê nesse fato uma oportunidade para se estabelecer um sistema econômico com outros parâmetros, ecologicamente mais sustentáveis, que não sejam mais medidos pela régua do crescimento. A viabilidade de um novo paradigma solidário a ser construído a partir dessa "anomalia" é o que pretendo discutir a seguir.

\footnotetext{
${ }^{22}$ No dizer de Kuhn: "Descoberta começa com a consciência da anomalia, ou seja, com o reconhecimento de que a natureza de alguma forma violou as expectativas induzidas pelo paradigma que governa a ciência normal. Então continua com uma exploração maior ou menor da área de anomalia. E fecha-se somente quando a teoria do paradigma foi ajustada para que o anômalo torne-se o esperado. Assimilar um novo tipo de fato exige uma regulação mais aditiva de uma teoria, e até que esse ajuste seja concluído - até que o cientista tenha aprendido a ver a natureza de uma forma diferente - o fato novo ainda não é totalmente um fato" (Tradução livre. KUHN, 1970, p. 53).

${ }^{23}$ Por exemplo, a própria projeção do Banco Mundial, em 08 jun. 2020, disponível em https://www.worldbank.org/en/news/feature/2020/06/08/the-global-economic-outlook-during-the-covid-19pandemic-a-changed-world. Acesso em: 29 jul. 2020.
} 


\section{ARTIGO}

INOVAÇÃo

\section{A VIA ANÔMALA: DO NOMOS IMPERATIVO AO LOGOS SOLIDÁRIO}

Para ir direto ao equívoco: a via anômala é a que vai da economia política à ecologia política. $\mathrm{O}$ acontecimento pandêmico é, assim, aquele que abre uma bifurcação na economia política no sentido de que esta "não dá mais conta". Esse não dar conta se faz nos vários sentidos do termo contar: é um paradigma que não permite ao acontecimento uma resolução semântica para que seja narrado, descrito ou entendido; e também aquilo que foge à sua contabilidade, por não poder ser quantificado. Sem contabilidade numérica e quantitativa o capitalismo "equivoca", "falha" e se interrompe. A contabilidade é essencial para que a mais-valia possa ser "capitalizada", pois o capital é o que "acumula", e o capital a ser acumulado deve ser comparado em termos homogêneos a outros capitais já acumulados.

A economia é formada da soma do oikos, a casa segundo os gregos, com o nomos, a lei, ou a regra, isto é, aquilo que dita a sua "norma". Economia é a norma da casa. Mas como entender o nomos, afinal? Uma ideia é a de pensar o nomos como uma catacrese do logos. Catacrese é a figura da linguagem da "metáfora morta", como "pé da cadeira", uma metáfora que utilizamos porque não temos termo melhor e que acaba "vingando" no uso pragmático da língua. O nomos é a reificação do logos. Aquilo que foi $\log o s$, através de um período mais ou menos longo de aceitação ou imposição, acaba se tornando nomos, e a palavra se torna norma ou lei. É assim que a ciência sempre procedeu quando nos fez crer que suas descrições da natureza acabavam por fim se tornando as leis da natureza. Também o logos tenderá a se solidificar como nomos. Daí que a oikos-logia seja apenas a forma primitiva da economia política. Passar da economia para a ecologia política significa menos avançar uma nova concepção, que pode ser lida como certo progressismo, mas realizar antes uma anamnese, isto é, uma recuperação de seu sentido mais primário e oculto.

Por isso, o marxismo, elaborado como crítica da economia política deve, à maneira leninista, dar um passo atrás para dar dois à frente. O retorno à ecologia política serve para recuperar o logos sobre o qual foi edificada a economia política clássica do liberalismo. Só a ecologia política como novo paradigma pode fazer com que o marxismo critique o seu próprio produtivismo, isto é, a ideia de que a esfera da produção (definida pelo modo de produção) sustente a esfera social (onde a sociedade se dá enquanto sistema de relações). Foi a teoria substancialista de Karl Polanyi que fez a crítica mais radical dessa inversão. Em seu clássico $A$ Grande Transformação (2012 [1948]), Polanyi defendeu que a economia está sempre 
"incrustada" ou imbricada (embedded) ${ }^{24}$ na sociedade de que faz parte. A economia é um dos sistemas de toda sociedade e serve aos seus propósitos. A ideia de que a economia é um sistema à parte ou autônomo nasce com o capitalismo e com a ideologia do liberalismo. Adam Smith, por exemplo, um filósofo da moral, ao comentar sobre a famosa Fábula das Abelhas, de Bernard Mandeville (1723), na qual os vícios privados provocam benefícios públicos, descobria que o egoísmo era a principal virtude da economia de mercado; no entanto, isso era incompatível com a ética pública na qual o egoísmo não poderia se constituir como a base moral da sociedade. A solução para Smith foi estabelecer o sistema de mercado como um sistema autônomo, no qual um empresário (sempre do gênero masculino e branco) poderia exercer livremente sua avidez por lucros na fábrica, e após a jornada de trabalho retornar ao ambiente doméstico como um respeitável e honesto pai de família ${ }^{25}$. Nesse mito de apartação entre o espaço da fábrica e o espaço doméstico reside a própria distinção entre espaço de produção (economia) e espaço de reprodução (sociedade). Esse é o fundamento da ideologia produtivista na qual a economia é o sistema de produção de "produtos", individualizados, para serem "usados" ou "consumidos" na esfera social. Essa também é a lógica da mercadoria enquanto produto individualizado (capitalizado) com um valor "próprio". No entanto, nas sociedades não capitalistas não se produzem produtos, mas meios para possibilitar alguma atividade social. Uma comunidade de indígenas não produz um cesto como um produto, mas enquanto um meio de armazenar alimentos dentro de uma atividade social específica. Polanyi fez a crítica da sociedade de mercado como processo para "desimbricar", para estabelecer um espaço autônomo e independente. Porém, para o antrópologo austríaco tal movimento é totalmente inviável. A economia não consegue se desimbricar da sociedade e essa tentativa não pode deixar de causar um movimento contrário da sociedade de "reimbricação" da economia ${ }^{26}$.

No entanto, é precipitado acreditar que a teoria marxiana é necessariamente produtivista. Embora essa seja outra questão que não é possível retomar nos limites deste artigo, é preciso lembrar que o conceito de trabalho em Marx é o de "atividade metabólica" e que em vários trechos de sua obra o alemão irá colocar o trabalho humano exatamente na fronteira da relação entre sociedade e natureza, onde o aparato técnico incide. E a esfera da técnica, isto é, do modo de produção, é antes o traçado entre sociedade e natureza do que uma esfera

\footnotetext{
${ }^{24}$ A tradutora da versão brasileira aqui utilizada, Fanny Wrobel, traduziu o termo embeddness por "incrustação" pela relação do termo original com as minas de minério na Inglaterra. Usamos "imbricação" rigorosamente no mesmo sentido por conveniência.

${ }^{25}$ Para esta leitura cf. Adam Smith's Third Party: the Spectator, in: DUPUY, Jean-Pierre. Intersubjectivity and embodiment. Journal of Bioeconomics, The Netherlands, n. 6, p. 275-294, 2004. Disponível em https://www.academia.edu/30741148/Intersubjectivity_and_Embodiment. Acesso em: 31 jul. 2020.

${ }^{26}$ Polanyi chamou esse movimento de desimbricação-reimbricação como "duplo movimento".
} 
independersrnte. Em particular, o tema crucial ecossocialista da "falha metabólica" (metabolic rift), isto é, da fratura crescente entre o humano e a natureza, foi levantado na última fase dos estudos de $\operatorname{Marx}^{27}$.

A ecologia política se torna assim um termo mais relevante do que o de economia ecológica, pioneiramente introduzido no Brasil por Clóvis Cavalcanti. Cavalcanti foi responsável por situar novamente a economia na fronteira entre sociedade e natureza e trouxe as contribuições cruciais do economista Nicholas Georgescu-Roegen para o debate brasileiro. Georgescu-Roegen foi um dos pensadores que incluiu os impactos da economia capitalista nos ecossistemas no interior do sistema econômico. No paradigma da economia clássica liberal, os impactos ecológicos são uma "externalidade", e a natureza é vista como um "apêndice" e um recurso a ser utilizado. O economista romeno contrastava a infinitude dos ciclos capitalistas de crescimento com os recursos finitos dos ecossistemas energéticos. Georgescu-Roegen também acrescentou a essa assimetria energética a questão ainda mais relevante do aumento contínuo de entropia e cunhou como lógica do sistema produtivo capitalista a sequência do "produzconsome-descarta". Essa lógica, além de ser recursivamente infinita, também é crescentemente entrópica. Para Cavalcanti, a função da economia ecológica é pensar em termos integrados a relação entre produção e ecossistemas, ou seja, é pensar o sistema econômico como integrante do ecossistema físico e biológico do planeta ${ }^{28}$.

A economia ecológica introduz o tema do balanço entrópico. O problema maior não é a escassez energética, mas a entropia que é dada pela segunda lei da termodinâmica, que diz que a entropia sempre aumenta. $\mathrm{O}$ balanço entrópico não se conserva, sendo sempre positivo. Assim, o ciclo produz-consome-descarta é triplamente entrópico: há entropia na produção (sobretudo na extração), no consumo (que basicamente é uma operação entrópica) e no descarte (em que o lixo se torna um dejeto entrópico). Um efeito óbvio do ciclo de crescimento acelerado do capitalismo é o aquecimento global. A queima de imensas reservas de petróleo, guardadas com baixíssima entropia sob a crosta terrestre, e sua dissipação na atmosfera, na forma de gases com alta entropia, conduz a uma "entropização" da atmosfera terrestre cujo efeito mais

\footnotetext{
${ }^{27}$ Para o principal teórico dessa linha ecossocialista, John Bellamy Foster, a epidemia do coronavírus é exatamente um efeito da "fratura metabólica" pioneiramente observada por Marx. Pode-se simplesmente imaginar como o vírus penetrou por essa "fratura" e contaminou a sociedade global a partir de sua esfera econômica. Cf. FOSTER, John Bellamy. "Uma catástrofe no século XXI, a menos que a humanidade mude subitamente de rumo". IHU notícias, São Leopoldo, 08 abr. 2020. Disponível em: http://www.ihu.unisinos.br/78-noticias/597888-umacatastrofe-no-seculo-xxi-a-menos-que-a-humanidade-mude-subitamente-de-rumo-entrevista-com-johnbellamy-foster. Acesso em: 31 jul. 2020.

${ }^{28}$ Para conhecer os conceitos da economia ecológica de Cavalcanti, ver CAVALCANTI, Clóvis. Concepções da economia ecológica: suas relações com a economia dominante e a economia ambiental. Estudos avançados, São Paulo, v. 24, n. 68, 2010. Disponível em: https://www.scielo.br/scielo.php?script=sci_arttext\&pid=S010340142010000100007. Acesso em: 03 ago. 2020.
} 
perceptível é seu aquecimento. O aquecimento global nos mostra o sistema capitalista como uma bomba entrópica. No entanto, os ecossistemas, que são sistemas organizados, isto é, sistemas de "neguentropia", são capazes de assimilar (metabolizar) uma capacidade finita e específica de entropia. Quando ultrapassada essa capacidade, o ecossistema começa a perder suas “distinções”, ou seja, sua capacidade de autodiferenciar e, com isso, auto-organizar. Esse é o desafio central que a humanidade enfrenta neste século, e está claro que o aquecimento global é causado pela intervenção humana. A esse conhecimento se deu o nome de Antropoceno, isto é, uma nova era geológica em que as "pegadas" da espécie do Homo sapiens se mostram capazes de influir (ou refluir) nos ciclos geológicos do planeta ${ }^{29}$.

Para o escopo deste ensaio, convido a pensar a pandemia do coronavírus como mais um sintoma do desequilíbrio ecológico proporcionado pelos ciclos produtivistas e "crescimentistas" do capitalismo; por isso, uma crítica da pandemia só pode surgir a partir do paradigma da ecologia política. É possível imaginar a seguinte hipótese: a crescente digitalização e automação dos sistemas técnicos, a partir sobretudo deste novo século, acelerou de forma ainda mais aguda a velocidade dos ciclos econômicos. A financeirização da economia, potencializada pela digitalização, criou um curto-circuito no capital, do tipo "capital gera capital". Em 2008, que ocorreu logo após a primeira epidemia da SARS, uma das "soluções" para a crise econômica foi a modalidade do quantitative easing, isto é, a liberação espetacular de moeda para recompra de títulos e acções "podres” de bancos semi-falidos. Foi uma geração monstruosa de moeda sem lastro. Na teoria econômica clássica, tal liberação monetária deveria necessariamente gerar um surto global inflacionário que não ocorreu, ou ocorreu em poucos países (como Venezuela, Argentina e Turquia, e parcialmente no Brasil e na Rússia em 2015).

Como essa pandemia inflacionária foi debelada ou bloqueada? Por dois meios: em primeiro lugar, por um rebaixamento dos preços de "commodities", isto é, dos produtos da extração primária dos recursos naturais. Isso correspondeu literalmente a um "barateamento" da natureza. Com essa medida evitou-se uma maxidesvalorização do dólar. O segundo aspecto é que, na contracorrente da necessidade de se reduzir a velocidade dos ciclos econômicos extrativistas, altamente entrópicos, houve um empuxo de aceleração dos ciclos extrativistas. Esse aumento de produção foi tomado como necessário para "lastrear" o excedente de moeda lançado no mercado. Essa aceleração facilmente explica, por exemplo, os desastres ecológicos de Mariana e Brumadinho, pois o valor dos minérios foi reduzido à metade e para se manter os lucros a produção mineral teve que dobrar, e com isso a geração de dejetos ultrapassou os

\footnotetext{
${ }^{29}$ Não irei debater neste artigo a pertinência do conceito de Antropoceno, termo definido pelo químico Paul Crutzen no ano de 2000 e ainda não oficialmente adotado pelas principais sociedades geológicas do mundo.
} 
limites de segurança. Isso também explica a produção insana de empreendimentos imobiliários, necessários para "dar vazão" a esse extrativismo acelerado, com a geração em todo o globo de centenas ou milhares de "condomínios fantasmas"

Mas a intensificação do extrativismo não se deu apenas na mineração: foi na verdade uma regra geral da economia para lidar com a crise de 2008. Assim, monoculturas extensivas na agricultura e pecuária, monópolios industriais e de serviços corresponderam também à homogeneização de várias camadas da economia, que caminhou pari passu com a sua financeirização digital. Ora, essa homogeneização econômica, cuja finalidade foi acumular capital para lastrear as montanhas etéreas de pseudo-moeda, produziu uma espécie de monoculturalização da economia em diversas áreas, com a perda completa de complexidade econômica ${ }^{31}$. Para vários especialistas, a pandemia é um resultado dessa perda de complexidade na esfera da produção alimentar, sobretudo com as imensas fazendas bovinas, suínas e aviárias na Ásia, que são fontes de transmissão de vírus como "pragas genéticas"32. Essa perda de diversidade também se assiste naquele que seria o nível mais sofisticado da economia, o da economia dos dados. Pois justamente nessa esfera mais avançada da economia se formaram grandes monopólios informacionais, infamemente conhecidos como Gafam - Google, Apple,

Facebook, Amazon e Microsoft. Essas cinco versões do capitalismo de plataforma concentram mais de $90 \%$ do tráfego da internet.

A hipótese é, afinal, de que o vírus se aproveitou da fragilidade dos ecossistemas produtivos cujos ciclos se aceleraram e se homogeneizaram. Se por um lado a homogeneidade dos sistemas propiciou um caldo propício para as mutações virais, por outro a mesma aceleração do sistema produtivo (ou tecnocientífico) acelerou sua propagação. E, ao mesmo tempo, a sua "tradução" de vírus biológico (baseado em código genético) em vírus digital (baseado em código binário) foi a passagem que permitiu à pandemia se acoplar a uma infodemia. Como disse o importante teórico da informação Yui Hui, a baixa "tecnodiversidade" dos sistemas também é um ambiente propício para proliferação de vírus digitais. Para aumentar a “imunidade

\footnotetext{
${ }^{30}$ A região portuária no Rio de Janeiro é um dos exemplos mais cabais desse empuxo especulativo imobiliário.

${ }^{31}$ Complexidade econômica é um conceito do físico e economista chileno César Hidalgo. A teoria tenta representar as economias em termos de sua complexidade. Quanto mais complexa é uma economia, quanto mais sua pauta de exportação tem produtos com grande "informação", isto é, produtos que são ao mesmo tempo raros e não úbiquos. Produtos complexos demandam cadeias produtivas longas para serem produzidos e essas cadeias diversificam uma economia. O Brasil tem perdido desde os anos 90 sua complexidade econômica, o que seria para esses economistas a principal razão tanto da desigualdade como da pobreza. No Brasil, o maior especialista nesse campo é o economista Paulo Gala da FGV de São Paulo. Ver GALA, Paulo, O Atlas da Complexidade Econômica: um novo breakthrough empírico para os economistas estruturalistas. São Paulo: 15 nov. 2018. Disponível em: https://www.paulogala.com.br/o-atlas-da-complexidade-economica-um-novo-breakthroughempirico-para-os-economistas-estruturalistas/. Acesso em: 03 ago. 2020.

32 Ver nota 6.
} 
tecnológica" dos sistemas técnicos é também preciso aumentar sua tecnodiversidade. Nesse aspecto, as redes digitais são um fármaco: tanto são remédios quanto venenos. Devemos pensar que uma economia complexa pode ser vetorizada por uma complexidade técnica sem que isso signifique construir novas barreiras ou muros imunológicos (quase sempre nacionalistas, racialistas ou xenofóbicos) $)^{33}$. Para tanto é preciso fazer das redes digitais catalisadores (meios) para redes solidárias. O logos ecológico deve nortear uma mudança de paradigma que faça das palavras (comunicações, diálogos, interlocuções) os fios tecidos das malhas sociais que funcionarão como rede de frenagem à propagação de agentes nocivos e tóxicos, biológicos ou informacionais.

\section{DO PRODUTIVISMO À CRÍTICA DA REPRODUÇÃO SOCIAL}

É pouco observado no ensaio seminal de Walter Benjamin, A obra de arte na era da reprodutibilidade técnica (BENJAMIN, 1993), o conceito-chave de que a reprodutibilidade técnica marca uma nova era para o capitalismo enquanto modo de produção. Benjamin é um dos primeiros a observar que a distinção entre modo de produção e de reprodução passa a ser insustentável diante das novas técnicas. Essa distinção inicialmente separa a esfera produtiva, onde as máquinas produzem produtos, e a esfera reprodutiva onde os trabalhadores e, sobretudo, as trabalhadoras, se reproduzem. E embora possa ser feita uma distinção do industrialismo como uma forma de replicação diferente da reprodução genética, é fato que há antes semelhanças do que diferenças. Não é difícil justamente imaginar que as mercadorias são filhas da "cópula" entre o trabalhador e a máquina. E embora se possa dizer que Marx não foi certamente um autor que prestou suficiente atenção à questão de gênero na formação do capitalismo moderno, como acertadamente criticam muitas feministas socialistas, por outro lado o autor alemão teve uma intuição de gênio ao classificar o trabalhador, em sua generalidade, como "proletário", aquele cuja única riqueza é a sua prole, isto é, aquele cuja fortuna são suas "forças reprodutivas".

Isso quer dizer que Marx localiza o trabalhador do lado da reprodução social e não do lado da produção capitalista, onde ele entra como ser "alienado". A passagem do trabalho vivo ao trabalho abstrato e daí ao trabalho morto é uma reificação de seu caráter vivencial e reprodutivo. Esse viés nos permite enxergar no capitalismo um sistema estéril, que é incapaz de se reproduzir por si mesmo, dependendo para isso de um acoplamento "parasitário" com a

\footnotetext{
${ }^{33}$ HUI, Yuk. Cem anos de crise. São Paulo: N-1 Edições, 2020. Disponível em https://n-1edicoes.org/059. Acesso em: 03 ago. 2020.
} 
esfera da reprodução social. O capital não pode gerar capital a partir de si mesmo, ele não é um "sistema autopoiético". No dizer dos biólogos Humberto Maturana e Francisco Varela, criadores da teoria da autopoiese, o capitalismo é uma "máquina alopoiética" (MATURANA; VARELA, 2002).

A fronteira, portanto, entre sistema produtivo e sistema reprodutivo foi, desde sempre, problemática. O desenvolvimento das técnicas de reprodutibilidade técnica, que sempre esteve pressuposta dentro da técnica industrial, tornava ainda mais fluida essa fronteira. As técnicas de digitalização então intensificam enormemente essa reprodutibilidade técnica a ponto de tornar insustentável a distinção entre esfera produtiva e esfera reprodutiva. Talvez este seja o maior impacto tecnológico das últimas décadas: uma impossibilidade cada vez maior de realizar o que Polanyi definia como a desimbricação do sistema econômico. Acontece que o neoliberalismo, que se torna a partir dos anos 70 o modo dominante de regulação da economia, inverte essa tendência. Como observaram muitos estudiosos, e Michel Foucault antes de todos, o neoliberalismo é mais do que simplesmente um novo sistema econômico que, como o antigo liberalismo, procura se desembarcar do sistema social; antes, procura subsumir a própria esfera da reprodução à sua lógica. Não se trata, portanto, de se construir um sistema à parte, mas fazer da própria sociedade seu espelho. O mercado passa a ser um mapa sobre a sociedade, e os indivíduos passam a se assumir dentro de uma subjetividade empresarial, como se fossem empresas (fenômeno no Brasil conhecido como "pejotização") ${ }^{34}$. Assim, a desimbricação não se torna mais necessária e o mercado passa a ser um "modelador" da sociedade numa esfera integrada.

Esse movimento de subsunção neoliberal da esfera de reprodução social foi facilitado pela informatização da infraestrutura pela via da automação e pelo estabelecimento de protocolos e plataformas digitais. O movimento autonomista italiano foi um dos primeiros a entender esse processo pelos conceitos de "fábrica social" e "trabalho imaterial" (HARDT; NEGRI, 2001). O espaço segregado da fábrica é expandido por todo o território social. A digitalização progressiva da infraestrutura "encapsulou" esse processo pela adoção generalizada dos códigos binários da computação. A computação passou a ser a forma social universalizada de processamento das diferenças. A simetria dos códigos binários dá vez à "cismogênese" dos grupos sociais e ao "colapso de contexto" que é antes de mais nada um

\footnotetext{
${ }^{34}$ DARDOT; LARVAL, 2016. O principal livro de Foucault que estuda o neoliberalismo é $O$ Nascimento da Biopolítica (São Paulo: Martins Fontes, 2008). Cf. AVELINO, Nildo. Foucault e a racionalidade (neo)liberal. Revista Brasileira de Ciência Política, Brasília, DF, n.21, set./dez. 2016. Disponível em https://www.scielo.br/ scielo.php?script=sci_arttext\&pid=S0103-33522016000300227. Acesso em: 05 ago. 2020.
} 
apagamento de fronteiras ${ }^{35}$. Mas esse colapso contextual não é simplesmente a produção de uma esfera "virtual" onde agora se dão as trocas econômicas, mas sim a assimilação do sistema de menor variedade pelo de maior variedade ${ }^{36}$.

O que significa viver numa situação em que o modo de produção capitalista já não se estabeleça dentro de esfera autônoma e reconhecível? Essa é provavelmente a mais importante questão econômica de nossos dias. Ainda não é possível dar uma resposta consistente a esta pergunta, mas é importante constatar que, desde muito, foi a crítica feminista e socialista que primeiro compreendeu essa questão. E isso se dá sobretudo porque desde a formação do sistema capitalista as mulheres estiveram numa situação de "trabalho não remunerado". Assim, à medida que se estabelecia, a partir da revolução industrial inglesa no final do século XVIII na Inglaterra, o trabalho remunerado (majoritariamente masculino e branco) foi tido como o único trabalho "reconhecido" enquanto produtivo no interior da esfera econômica segregada. As mulheres eram consideradas fora dessa esfera e os trabalhos doméstico, sexual e de formação, educação das crianças, de limpeza e ordenação do "lar", eram considerados "não trabalhos", e portanto sem direito à remuneração. A esses trabalhos não remunerados também se deve acrescentar todo o trabalho escravizado de pessoas de cor nas colônias durante o século XIX. O trabalho reprodutivo, isto é, ligado a todas as atividades metabólicas necessárias à conservação e reprodução da sociedade, foi sempre negligenciado e colocado do lado de fora da esfera capitalista de produção. No entanto, esse trabalho é fundamental para a reprodução da própria "força de trabalho" que vem a ser justamente os corpos dos trabalhadores, bem como a manutenção de suas funções vitais. Mas essa força de trabalho é, ela própria, reificada em "mercadoria" ao entrar na esfera de produção ${ }^{37}$. Isso significa que o capitalismo se formou com uma enorme "expropriação" de capital primitivo que é fornecido gratuitamente ao sistema capitalista por esse trabalho invisibilizado. O corpo feminino era observado como uma máquina reprodutiva de força de trabalho (FEDERICI, 2017 e 2019). Foi essa invisibilidade que permitiu a teóricas feministas do capitalismo a dianteira da crítica de como a informatização técnica iria não apenas colapsar as fronteiras entre o sistema produtivo e reprodutivo, como a concluir que esse colapso levaria a uma feminização da força de trabalho e a sua crescente precarização. A

\footnotetext{
${ }^{35} \mathrm{O}$ conceito de cismogênese vem da teoria cibernética de Gregory Bateson no artigo Culture contact and Schismogenesis in BATESON, 2000. O conceito de "colapso de contexto" tem sido aplicado pela pesquisadora Leticia Cesarino para estudar o impacto das mídias socials no contexto político brasileiro. Cf. CESARINO, Letícia. Identidade e representação no bolsonarismo. Revista de Antropologia da USP, São, Paulo, v. 62, n. 3, p. 530-557, 2019. Disponível em http://www.revistas.usp.br/ra/article/view/165232. Acesso em: 05 ago. 2020.

${ }^{36}$ Isso se dá por causa do conceito cibernético de "variedade requerida" (requisitive variety) de Ross Ashby (1970), na qual um sistema de menor variedade só pode ser assimilado por um de maior e nunca o contrário.

${ }^{37}$ Marx e Polanyi compreenderam a mercadorização da força de trabalho como "trabalho fictício", pois a força de trabalho só pode ser entendida como a própria existência física e mental do trabalhador.
} 
bióloga Donna Haraway, em seu seminal texto dos anos 80, o Manifesto Ciborgue (1985), já previa essa consequência, que ela chamava de circuito integral (sem fronteiras) da "informática da dominação" 38 .

Atualmente, é no movimento feminista e na teoria da reprodução social (ARRUZZA; BHATTACHARYA; FRASER, 2019) que se faz a crítica mais aguda da precarização do trabalho ao relacioná-la historicamente ao trabalho não remunerado das mulheres. E isso se dá exatamente pelo fato de que esse movimento já trabalha há muito sobre a falsa fronteira entre produção e reprodução. Essa separação só pode ser mantida através de um muro ilusório e ideológico, que se concretiza, por exemplo, no debate nacionalista xenófobo e anti-imigração, sobretudo nos países das economias centrais do capitalismo. Se o marxismo sempre se compreendeu como um movimento internacionalista, chegou a hora de escutar com atenção a teoria do feminismo socialista para atravessar mais essa fronteira entre produção e reprodução e com isso gerar novas imagens das lutas de classes contemporâneas. O imperativo para que os trabalhadores do mundo se unam se faz inicialmente derrubando os muros invisíveis que separam os modos de vida e os modos de exploração.

\section{A ECOLOGIA POLÍTICA DAS ECONOMIAS BARROCAS}

A incapacidade de lidar com o colapso de contexto entre as esferas produtiva e reprodutiva talvez explique a impotência das esquerdas parlamentares frente ao cenário de mudança. Devemos menos considerar tal dificuldade em termos morais, como uma suposta nostalgia do paradigma anterior, do que enquanto incapacidade cognitiva, pois há uma perda de referências se as ações reformistas ou revolucionárias das esquerdas tinham sempre como premissa a separação entre o mundo do trabalho e o mundo da sociedade. Esse é um dos motivos pelos quais a extrema direita tem conseguido lograr mais sucesso político: porque a virada conservadora, na moral e nos costumes, coloca a esfera reprodutiva social como palco do embate político. Por outro lado, para as elites econômicas que querem explorar o novo "espaço econômico" da economia virtual, embora este pareça inteiramente dominado, na verdade lhe escapa o controle, pois a distinção espaço produtivo-reprodutivo lhe era igualmente crucial para a contabilidade da mais-valia gerada. A mais-valia é um excedente sistêmico que deve ser calculado num interior delimitado da economia. Se não se sabe mais onde começa e onde acaba

\footnotetext{
${ }^{38}$ HARAWAY, Donna. J. Manifesto ciborgue: ciência, tecnologia e feminismo-socialista no final do século XX. [S. n.: s. l., 2017]. Disponível em: https://cochabambahotel.noblogs.org/files/2017/03/Manifesto_Ciborgue.pdf. Acesso em: 05 ago. 2020.
} 
sua esfera de atuação (ou de exploração), o cálculo computacional da "máquina cibernética mercantil" não consegue mais ser realizado. Esse é um dos principais motivos do completo descolamento entre o valor financeiro do capital e seu valor monetário real, cujo índice mais grave é a insustentável dívida pública e privada, sendo esta última pelo menos o dobro da primeira, e ambas juntas pelo menos três vezes maior do que o valor reunido do PIB global, segundo os relatórios do $\mathrm{FMI}^{39}$.

No Brasil, em particular, o neodesenvolvimentismo foi o núcleo ideológico de gestão pública durante os anos de governo do Partido dos Trabalhadores (PT). Embora seja necessária a defesa dos acertos dessa governança na redução da extrema pobreza, é preciso pontuar que, a partir da segunda década do novo século, esse paradigma claramente já não conseguia lidar com os efeitos decorrentes da crise de 2008. A instabilidade econômica foi um dos principais fatores que levou ao processo (golpista) de impeachment da Presidente Dilma Rousseff. O balanço desse período está sendo feito por muitos intelectuais e não é objeto desse artigo. Qualquer que seja o resultado desse balanço, contudo, é certo que um retorno às linhas do neodesenvolvimentismo baseado em crescimento econômico não será mais viável. Basicamente, o produtivismo neodesenvolvimentista não é mais capaz de processar as mudanças da esfera do trabalho e da vida social que ocorreram com a digitalização das tecnologias produtivas e também com as crescentes restrições ambientais que só poderão se tornar cada vez mais rigorosas ${ }^{40}$.

Por isso, a via anômala aberta pelo acontecimento pandêmico, exatamente por sua abrangência global, mostra uma oportunidade de rever este paradigma desenvolvimentista e fornecer uma nova base teórica para que as esquerdas consigam sair do jogo culturalista conduzido com sucesso pela extrema-direita, ou pelo "populismo digital" autoritário, cuja

${ }^{39}$ INTERNATIONAL MONETARY FUND. Gross debt position: \% of GDP. Washington, DC, 2020. Disponível em: https://www.imf.org/external/datamapper/G_XWDG_G01_GDP_PT@FM/ADVEC/FM_EMG/FM_LID C. Acesso em: 06 ago. 2020.

${ }^{40}$ Curiosamente, foi o mais importante pensador do desenvolvimento nacional, Celso Furtado, já em 1974, citando expressamente Nicholas Georgescu-Roegen, quem já alertava para a inviabilidade de um desenvolvimento econômico baseado em crescimento contínuo e infinito que levaria fatalmente ao colapso: "Antes de considerar que significado real cabe atribuir a essa profecia [do colapso], convém abordar um problema mais geral, que o homem moderno tem tratado de eludir. Refiro-me ao caráter predatório do processo de civilização, particularmente da variante desse processo engendrada pela revolução industrial. A evidência a qual não podemos escapar é que em nossa civilização, a criação de valor econômico provoca, na grande maioria dos casos, processos irreversíveis de degradação do mundo físico. O economista limita a sua observação a processos parciais, pretendendo ignorar que esses processos provocam crescentes modificações no mundo físico. A maioria deles transforma energia livre ou disponível, sobre a qual o homem tem perfeito comando, em energia não disponível. Demais das consequências de natureza diretamente, como seja o encarecimento das fontes alternativas de energia, esse processo provoca elevações de temperatura média de certas áreas do planeta, cujas consequências a mais longo prazo dificilmente poderiam ser exageradas. A atitude ingênua consiste em imaginar que problemas dessa ordem serão solucionados necessariamente pelo progresso tecnológico, como se a atual aceleração do progresso tecnológico não estivesse contribuindo para agravá-los" (FURTADO, 1974, p. 17-18). 
principal estratégia é dispensar a governança econômica ao neoliberalismo financeiro e focar em questões morais. Mas, para dar esse passo, é preciso sair do campo da economia política para o campo mais abrangente da ecologia política. E não só porque esse passo inclui a relegada questão da transição ecológica - um dos pontos mais fracos da direita populista, que é incapaz de se estabelecer nesse campo, pois contraria seus interesses de defesa da economia extrativista -, mas também porque é no campo da ecologia politíca que se incluem os problemas crescentes da reprodução social, que afligem diretamente as vidas e os corpos de milhões ou bilhões de trabalhadores e trabalhadoras. Assim, mudar o "campo do jogo" pode ser a estratégia mais eficaz para que as esquerdas consigam "virar" a batalha agônica que está sendo travada pela democracia. Sobretudo porque, em qualquer cenário crível, a transição ecológica para uma sociedade que reduza o consumo energético baseado em carbono, bem como reduza o desperdício entrópico das atividades econômicas, deverá ser um imperativo incontornável.

O primeiro passo a seguir será o de recusar uma visada "totalitária" ao neoliberalismo triunfante. Ou seja, deve-se recusar que a hegemonia neoliberal seja de fato imperante para todo território social. Aqui vale adotar a estratégia cibernética da distinção entre mapa e território, adotada por Gregory Bateson (1970): o mapa não é o território ${ }^{41}$. Se o neoliberalismo "ocupa" o Estado para se tornar o novo mapa simbólico da sociedade, esta como território não pode ser completamente coberta pelo mapa, pela lei da variedade requerida ${ }^{42}$. Isso significa basicamente que, embora hegemônico ou dominante, o neoliberalismo não pode reger todas as formas de troca simbólicas, produtivas e reprodutivas que acontecem na sociedade. A colonização social exercida pelo neoliberalismo não só encontra resistências entre vários modos distintos de sociabilidade - populares, indígenas, femininos, quilombolas, socialistas, ecossocialistas, anarquistas - como nesses modos de sociabilidade "heterogêneos" a produção e a reprodução sociais já são indistinguíveis. É a isso que chama a atenção a pesquisadora argentina Verónica Gago, em sua obra sobre as atividades de migrantes bolivianos em Buenos Aires (2018). Gago chama de "economia barroca" ao conjunto heterogêneo (ensamblagem) de pragmáticas econômicas e vivenciais de migrantes na periferia da capital argentina, no contexto grave de crise econômica desde o início do novo século, quando a Argentina enfrentou moratória e inflação, cenário que permanece até os dias atuais. A pesquisadora defende que na economia popular há muitas maneiras diferentes de traduzir o código hegemônico neoliberal, invertendo sua direção de acima-abaixo (top-down), para um "neoliberalismo de abaixo" (neoliberalismo

\footnotetext{
${ }^{41}$ Bateson se refere na verdade à teoria da "Semântica Geral" (General Semantics) de Alfred Korzybski, exposta em sua obra magna Science and Sanity (Ciência e sanidade).

${ }^{42}$ Cf. nota 35.
} 
de bajo). Apesar desse termo equívoco, o fundamental de sua análise é que não há exatamente uma fusão entre práticas heterogêneas das trocas e produção de valor, mas uma estrutura que se mantém fragmentada com lógicas próprias e mediações de tradução entre as fronteiras de microterritórios. Nesses territórios divididos não há mais distinção entre a produção de valor e a reprodução da sociabilidade, entre a lógica acumuladora do capital e a distributiva do "social" 43 .

É essa disputa entre valor-capital versus valor-social que está em jogo redefinindo as novas fronteiras, pois a questão não é apagá-las, mas retraçá-las para condições de luta mais favoráveis. Nisso, é preciso entender, ao menos pragmaticamente, que há um valor imanente do social. A reprodução do social é a reprodução desse valor, que se torna autovalor. Um valor de usufruto que não se acumula, mas se "dissemina" pela sociedade. Talvez valha a pena substituir a noção de "forças produtivas" pela de "impulsos reprodutivos" do social. Na esfera da reprodução social o mais-valor está na geração e no reforço daquilo que descreve a sociedade “em si”": seu ser de "relação".

\section{SOLIDARIEDADE E TECNOLOGIA SOCIAL}

A distinção mapa/território nos permite pensar fora do mapa neoliberal, cuja lógica de traço é a da regulação da mais-valia, o que pode ou não ser capitalizado. Fora das fronteiras desse mapa, há outros valores que não são regulados pelo protocolo algorítmico do neoliberalismo. Porém, o espaço do território não supõe um acesso "direto" que não seja mediado por outros mapas. Não há acesso imediato ao território (assim como não há mapa sem território). Isso porque a relação mapa/território supõe sempre "mapas de mapas", sendo cada mapa território de outro mapa. É uma relação e não uma formação de duas diferentes substâncias. É preciso entender também que o mapa está sempre “imbricado" em algum território. É uma relação homóloga à relação texto/contexto. Por isso é igualmente necessário mapear o território que se encontra fora do mapa dominante neoliberal.

A via anômala é uma equivocação, um desvio que adentra esse território social onde outras lógicas ecossistêmicas se organizam. É exatamente nesse território onde, embora marcado pela precariedade dos meios e pela vulnerabilidade dos corpos, a semente da anomalia

\footnotetext{
${ }^{43}$ Baseada na leitura do contexto argentino, a análise de Gago poderia nos ajudar a entender a polarização brasileira na eleição presidencial de 2018 em seu caráter marcadamente regional, quando os estados nordestinos destoaram dos estados sudestinos e sulinos e do centro-oeste. Talvez isso se dê justamente na oposição entre uma matriz produtiva-reprodutiva sudestina e sulina baseada na lógica neoliberal empreendedora, associada à matriz pentecostalista fortemente conservadora e puritana, e a matriz "barroca" e católica da economia nordestina que o período econômico do lulismo teria engendrado. Mas essa é uma hipótese para ser trabalhada em novo artigo.
} 


\section{ARTIGO}

INOVAÇÃo

pandêmica pode realmente germinar e se enraizar. Essas raízes se ramificam a partir da anomalia e crescem sob a opacidade das relações econômicas dominantes. Precisamos “desencavar" essas raízes para observar as possibilidades da via anômala. Só a partir dessa observação é possível construir narrativas consistentes. No entanto, toda observação nunca é espontaneamente obtida. Ela é uma perspectiva (olhar através) que atravessa um dispositivo (instrumento) que lhe dá foco. Aqui irei pensar a ecologia política da via anômala através da ferramenta conceitual da tecnologia social. A partir desta noção chegarei a uma fórmula de como as redes solidárias criadas durante a pandemia poderão se constituir como o meio (material) de uma economia solidária.

A tecnologia social (TS) é um instrumental teórico desenvolvido no Brasil sobretudo através das colaborações do professor Renato Dagnino, entre outros, e subsidiou o conceito de economia colidária desenvolvido por nomes como Paul Singer e Euclides Mance (2008). A TS é importante para pensar uma alternativa econômica para este contexto de catástrofe, primeiramente, porque sua base não é capitalista; segundo, porque parte de uma perspectiva latino-americana. A TS se diferencia da tecnologia convencional (TC $)^{44}$. Esta é uma visão da tecnologia enquanto empresarial capitalista baseada na propriedade dos meios de produção, e é a propriedade que define o controle dos usos dos meios de produção (DANIGNO, 2009).

A TC é assim determinada pelas orientações da classe capitalista para a apropriação de mais-valia, que, segundo Dagnino, é definida pelo controle do "tempo socialmente necessário". Essa apropriação resulta na alienação do trabalhador, em cuja produção está envolvido, na venda de sua força de trabalho, e não obedece mais aos seus critérios de satisfação de necessidades e desejos. O controle dos meios de produção coloca a tecnologia na subordinação do princípio do rendimento ou da eficiência, que é redução das entradas (input) para maximização das saídas (output). Esse princípio da eficiência se torna o "princípio da realidade" social. Em função disso, a tecnociência na sociedade capitalista tem uma função positivista de ser atalho a toda negatividade social, isto é, às suas condições de crítica (MARCUSE, 1967). No neoliberalismo o princípio de eficiência é codificado como decisão racional sobre custobenefício, que cada indivíduo-empresa deve realizar em qualquer ato de sua existência. A tecnologia convencional é sempre empregada para se aumentar a produtividade, porém esse aumento não acarreta um aumento do "tempo livre", mas sim uma redução (poupança) da mão

\footnotetext{
${ }^{44}$ Seguiremos aqui os roteiros teóricos de NOVAES; DIAS, Contribuições ao marco analítico-conceitual da Tecnologia Social e DAGNINO, em direção a uma teoria crítica da tecnologia. Ambos os textos em DAGNINO, 2009.
} 


\section{ARTIGO}

INOVAÇÃo

de obra. Assim, a TC empregada no modo de produção capitalista é necessariamente desempregadora, pois o trabalho é visto como custo de produção.

A teoria da TC no Brasil se deu em comparação com a tecnologia apropriada (TA) criada no contexto indiano, em particular com a contribuição de Gandhi na luta contra a colonização britânica (NOVAES; DIAS, 2009). A TA era uma defesa da tecnologia dos modos de produção camponeses indianos na agricultura e no artesanato, contra sua assimilação pela TC da exploração colonial capitalista. No entanto, a TA, enquanto modo de produção local, não conseguia ampliar seus modos de produção, nem difundir o saber gerado por eles exatamente porque este era por demais "particularizado" e não conseguia se expandir para além de esferas localizadas. Ao mesmo tempo, era financiada por atores não locais e estatais que lhe eram estranhos. Por isso, uma das principais reflexões da TS é sobre como romper o localismo imediato de sua circunscrição para poder se disseminar em outros domínios sociais que não os de sua origem específica. Além disso, a TS, embora contemple a agricultura orgânica e local, não pretende ser limitada ao meio rural, ou ainda, defende superar a distinção rural/urbano. Para a imbricação social de uma tecnologia, Dagnino desenvolveu o conceito de adequação sociotécnica (AST) (2009). A TS não supõe nem que a tecnologia determine o social (determinismo técnico), nem que a sociedade determine a tecnologia (determinismo social). Na verdade, há um conceito de construtivismo sociotécnico que admite a coconstrução entre técnica e sociedade. Isso implica a democratização da elaboração do código sociotécnico (technical code, FEENBERG, 2010) e a coletividade dos meios de produção para a implantação desse código. Isso seria viável através de uma nova defesa do cooperativismo.

Para não cair novamente no idealismo ou no utopianismo do movimento cooperativista, cuja concepção é de longa data, é preciso pensar nas suas formas de viabilidade. Ora, a TS não é um objetivo a alcançar, mas um novo modo de apropriação dos meios. É ela que dará liga a uma concepção de economia solidária (ES), que por sua vez será o terreno fértil de aplicação da $\mathrm{TS}^{45}$. É necessário antes resgatar a experiência da ES no seio do Partido dos Trabalhadores, e em especial no primeiro mandato do governo Lula (2003-2006), no qual foi criada uma Secretaria de Economia Solidária e um programa de fomento a iniciativas solidárias (Senaes) ${ }^{46}$. Embora a perspectiva da ES tenha sido progressivamente abandonada durante os quatro

\footnotetext{
${ }^{45}$ SINGER, Paul. Economia solidária versus economia capitalista. Sociedade e Estado, Brasília, DF, v. 16, n. 102, p. 100-112, dez. 2001. Disponível em: https://www.scielo.br/pdf/se/v16n1-2/v16n1-2a05.pdf . Acesso em: 07 ago. 2020.

${ }^{46}$ Sobre a Senaes, ver SINGER, Paul. Dez anos de Secretaria de Economia Solidária (Senaes). Mercado de trabalho, Brasília, DF, n. 56, p. 89-93, fev. 2014. Disponível em: http://repositorio.ipea.gov.br/bitstream/1105 8/3784/1/bmt56_econ02_dez_anos.pdf. Acesso em: 07 ago. 2020.
} 
períodos de governo petista em função de uma visão convencional da economia, produtivista e baseada no crescimento econômico para gerar excedentes monetários para políticas assistenciais, é possível imaginar que já há um repositório de conhecimento, não sendo portanto uma aposta inteiramente nova. Pode-se imaginar que o chamado boom das commodities durante a primeira década do século XXI se tornou um vetor de indução da TC no lugar da TS no governo popular brasileiro. Porém, a partir da segunda década do fim desse ciclo de recursos naturais hipervalorizados, a TS se torna cada vez mais uma alternativa viável. E os principais vetores são justamente a mudança do código sociotécnico, com a digitalização dos meios de produção, e a formação das redes solidárias digitais emergentes com o cenário pandêmico.

\section{O PLATAFORMISMO SOLIDÁRIO}

Renato Dagnino (2009) usa o conceito físico de "histerese" para argumentar que não é possível adotar o princípio da substituição de um modo de produção por outro, porque quando um modo de produção é adotado nunca é possível retornar a uma situação anterior à sua atuação, pois o espaço social foi "deformado" e o modo de produção mantém sempre resíduos fortificados de sua vigência. Dagnino argumenta que não é possível, a princípio, passar simplesmente do modo de propriedade individual dos meios de produção para a propriedade coletiva, mas que os dois modos terão que conviver assimetricamente num certo período de tempo. Em verdade, se a adoção de um novo modo de produção é uma mudança de paradigma, devemos seguir também a observação de Thomas Kuhn (1970) de que um paradigma nunca é simplesmente substituído por outro. Ao mesmo tempo, um paradigma nunca pode ser abandonado sem que haja paradigma alternativo disponível. Isso significa que adotar a tecnologia social deverá ser inicialmente sempre um modo periférico (mas não necessariamente subalterno) de organizar a economia.

Nesse sentido, o acontecimento da pandemia do coronavírus representa a anomalia que, se trabalhada como contra-hegemônica ao paradigma hegemônico, dá a oportunidade para formação desse paradigma alternativo. Seu impacto representa uma transformação decisiva na hegemonia neoliberal capaz de deformá-la e gerar uma histerese de sua configuração. A pandemia é uma catástrofe que altera as formas ideológicas e materiais dominantes. É preciso admitir que, mesmo antes da pandemia a hegemonia do neoliberalismo, o paradigma hegemônico já se achava em franca contestação. De fato, como afirmei anteriormente, a informatização e a automação da economia e sua invasão para dentro do espaço da reprodução social diluíram as fronteiras rígidas entre esses espaços (colapso de contexto), favorecendo uma 
reimbricação entre reprodução e produção das relações sociais, isto é, do próprio social enquanto espaço comunicativo.

É certo, no entanto, que o próprio sistema dominante tenta "hackear" essa transformação procurando capitalizá-la. A formação do capitalismo de plataforma ou de aplicativo é uma resposta do sistema dominante à transformação digital. Vige uma nova "expropriação" dos meios de produção que corresponde a um novo período de "acumulação primitiva" do capital. Isso se faz com as empresas de big tech, com a adoção massiva de protocolos de extração de dados para a comercialização dos padrões de comportamento digital. Trata-se de uma verdadeira economia de "extrativismo digital". Essa expropriação também é uma captura de conhecimento social através daquilo que Marx chamou de "intelecto geral”, que é a inteligência distribuída pelos processos de trabalho de rede (network). Essa captura vem acompanhada pela ideologia do "solucionismo técnico", cuja nova forma de governança algorítmica arquiteta uma substituição da soberania democrática pela soberania transferida a algoritmos digitais (MOROZOV, 2018).

Mas isso não significa que essa transformação digital não favoreça também a emergência de novas formas de organização produtiva. Nesse sentido, a pandemia se torna um verdadeiro período para laboratórios de experimentação social. O próprio Evgeny Morozov, conhecido por seu ceticismo quanto aos potenciais liberadores das redes de dados, especulou sobre a nova possibilidade de um "socialismo digital", com a apropriação das plataformas digitais pelos trabalhadores ${ }^{47}$. Aqui, a primeira questão teórica se refere à relação entre expropiação capitalista e apropriação trabalhadora do conceito de plataforma. A utilização do termo de "capitalismo de plataforma" não deve inibir o reconhecimento de que o conceito de plataforma foi forjado anteriormente dentro do repertório teórico-prático do cooperativismo, em particular anarquista. Desde o início do século XX, formou-se a ideia de "plataformismo", um conceito de práxis criado no seio do anarquismo ucraniano por Nestor Makhnov. O plataformismo era uma tentativa de construir uma base de operações comuns para a diversidade de tendências anarquistas e cooperativistas daquele início de século. As plataformas seriam uma

\footnotetext{
${ }^{47}$ Cf. MOROZOV, Evgeny. Digital Socialism? The Calculation Debate in the Age of Big Data. New Left Review, London, n. 116-117, mar./jun. 2019. Disponível em: https://newleftreview.org/issues/II116/articles/evgenymorozov-digital-socialism. Acesso em: 08 ago. 2020). Morozov relembra nesse artigo o debate entre planificadores e neoliberais, como Hayek. Esses últimos diziam que a planificação centralizada não era um método eficaz nem razoável de articular oferta e demanda, apenas a "ordem espontânea" era capaz de “computar" satisfatoriamente essa articulação. Porém, segundo Morozov, as plataformas digitais são uma nova maneira de realizar essa articulação com eficácia. No contexto brasileiro, o professor Eleutério Prado tem levado esse debate com a série de artigos "Socialismo, utopia inviável?". Ver PRADO, Eleutério. Socialismo, utopia inviável? Outras palavras, São Paulo, 28 jun. 2019. Disponível em: https://outraspalavras.net/alemdamercador ia/socialismo-utopia-inviavel-1/. Acesso em: 08 ago. 2020.
} 
forma de organizar as diferenças entre essas tendências ${ }^{48}$. No contexto das plataformas digitais, o cooperativismo de plataforma (SCHOLZ, 2016) já está bem desenvolvido, com várias experiências digitais. Em verdade, a existência de um "intermediador" digital da plataforma que recebe uma parte das transações realizadas em seu interior, como é o caso das plataformas uberizadas, é completamente desnecessária, configurando um completo parasitismo econômico ${ }^{49}$.

A questão que nos concerne aqui é saber se a histerese social provocada pela pandemia abre um espaço de experimentação para a formação de uma "economia barroca" de coincidentia oppositorium $^{50}$, unidade de contrários, para criação de plataformas alternativas. Pois se, de fato, a pandemia colocou a necessidade de uso mais intensivo das plataformas digitais, essa necessidade caminhou junto ao interesse pelo estabelecimento de redes solidárias locais de produção, inicialmente muito fortes na área da alimentação (agroecologia, pequenos produtores e mercados), mas logo expandidas para outras áreas econômicas. Há uma grande virtude nessas redes: elas quase sempre unem com eficiência seu caráter local ao caráter urbano mais deslocalizado, resolvendo assim, em parte, o problema de "escala" da produção local autogestionada. É possível dar um salto integrador com a questão da mobilidade, que, mesmo sendo o "laço fraco" dessa cadeia (pelas questões sanitárias e de remuneração), tornou-se rapidamente um setor "essencial" da economia. De fato, a emergência de uma "solidariedade digital", com redes de voluntarismo, financiamento e contribuição comunitários, e sobretudo, com redes de contatos e compartilhamentos, abre um capítulo novo e outra esfera de luta pela reapropriação das plataformas digitais, sob o signo da "solidariedade". Gostaria de encerrar este artigo falando nessa nova forma digital da solidariedade e abordando como ela pode ser utilizada para consolidar as plataformas, bem como dar sustentação a uma proposta virtuosa

\footnotetext{
${ }^{48}$ Sobre o plataformismo anarquista, consultar PLATAFORMISMO. In: Wikipedia: a enciclopédia livre. Disponível em: https://pt.wikipedia.org/wiki/Plataformismo. Acesso em: 03 ago. 2020. Sobre a proposta de Nestor Makhno, conf. MAKHNO, Nestor et al. Plataforma organizacional dos comunistas libertários. [Paris]: 1926. Disponível em: https://www.nestormakhno.info/portuguese/platform/org_plat.htm. Acesso em: 08 ago. 2020.

${ }^{49}$ Como observou recentemente a pesquisadora Isabela Guerreiro, é preciso igualmente se perguntar se a configuração de exploração exercida pelas plataformas do tipo uberizado configuram mesmo uma forma capitalista de exploração, ou mesmo outra mais "feudal" de expropriação não mais do valor do trabalho (maisvalia) mas da renda de uso, tal como se dava no feudalismo a expropiação da renda da terra dos vassalos pelos soberanos. Por isso, é preciso se perguntar igualmente se a demanda de "autonomia" dos entregadores em função do trabalho por aplicativo não seria aquele tipo de liberdade referido por Marx, no qual após os cercamentos agrários os trabalhadores estavam "livres" para serem explorados. Cf. GUERREIRO, Isabela. Cooperativismo e uberização. Outras palavras, [São Paulo], 03 ago. 2020. Disponível em: https://passapalavra.info/2020/08/13 3410/. Acesso em: 08 ago. 2020.

${ }^{50}$ Conceito de Nicolau Cusa que presidiu a estética barroca nos séculos XV, XVI e XVII, que constituiu justamente o período de transição para a consolidação do sistema capitalista.
} 
para a renda básica, que se tornou objeto mais recente de muitos debates sobre sua viabilidade ou pertinência.

\section{UMA PROPOSTA DE RENDA BÁSICA UNIVERSAL SEGUNDO O PARADIGMA DA ECONOMIA SOLIDÁRIA}

Para compreender uma ideia de solidariedade que não seja apenas um resultado do voluntarismo moral, é oportuno recorrer à antiga distinção de Émile Durkheim (2007) entre solidariedade mecânica e solidariedade orgânica. De maneira contraintuitiva, Durkheim diz que a primeira corresponde à solidariedade em comunidades onde seus moradores são obrigados, pelas restrições de mobilidade, a conviver uns com os outros, e a solidariedade assim se impõe enquanto dever ou ritual coletivo. Para Durkheim, é na interdependência gerada pela divisão do trabalho que se cria a solidariedade orgânica, quando os trabalhadores não detêm mais o domínio e o saber de sua atividade e se tornam dependentes do trabalho de outros trabalhadores. É desse modo que a solidariedade deixa de ser um imperativo moral para se tornar uma necessidade estrutural. Essa relação está inscrita em sua etimologia, pois a palavra vem do latim solidus, que indica a relação recíproca dentro de um corpo físico (quanto mais forte é essa relação, mais sólido o corpo $)^{51}$. É a solidariedade orgânica que estava na base das organizações dos trabalhadores, notadamente nas sindicais que conseguiram importantes conquistas para a classe trabalhadora durante os últimos 150 anos, a começar pela limitação da jornada de trabalho. No entanto, é verdade que uma das estratégias neoliberais foi justamente minar essa solidariedade orgânica dos trabalhadores pela individualização e pelo fetichismo de consumo, ou disseminando a ideologia do trabalhador como microempresário que possui um "capital" que é a sua força de trabalho. Essa solidariedade tornou-se cada vez mais abstrata, retrocedendo à esfera moral, onde acaba se confundindo com o altruísmo ou a caridade.

O que a pandemia trouxe de novo é exatamente o resgate dessa concepção orgânica de solidariedade. Para o pensador italiano Franco Berardi, o cenário da pandemia traz uma reativação do corpo à esfera política e do útil na esfera econômica ${ }^{52}$. Esse retorno do corpo e do útil vem junto com uma enorme precariedade, com a vulnerabilidade sanitária e com o medo em relação ao futuro. Com o fracasso de muitos Estados em lidar com a pandemia, com as

\footnotetext{
${ }^{51}$ Diderot é o primeiro a utilizar o termo solidaire em seu sentido político, quando falava em ser "solidário a uma causa", ou seja, estar ligado a essa causa.

52 BERARDI, Franco. Bifo Berardi: a frugalidade como pensamento radical. Outras palavras, São Paulo, 16 abr. 2020. Disponível em: https:/outraspalavras.net/outrasmidias/bifo-a-frugalidade-como-pensamento-radical/. Acesso em: 09 ago. 2020.
} 
incertezas da ciência e da economia, as comunidades voltaram a ser um fator fundamental para a sobrevivência coletiva. Mas a comunidade agora vem marcada por um desprendimento (ou desenraizamento) da localidade, portanto não resulta na solidaridade mecânica aludida por Durkheim. Como também observa um dos maiores pensadores da economia solidária, Euclides Mance, a pandemia revela uma fenda sistêmica no capitalismo a partir da consolidação de uma constelação de fissuras que antes estavam invisibilizadas. Essa consolidação corresponde não só ao aparecimento da fenda, mas também é a base de solidez da solidariedade. Por essa fenda é possível construir os "circuitos econômicos solidários" através de "plataformas virtuais", digitais e analógicas, que reúnam a diversidade de redes solidárias locais que se organizaram durante a pandemia ${ }^{53}$. A construção dessas plataformas (ou da plataforma) passa por uma reapropriação das novas tecnologias digitais, ligando-as com as tecnologias sociais dos saberes comunitários que se organizam através do trabalho local. Essa é a base do que Euclides chama agora de economias transformadoras ${ }^{54}$.

As plataformas virtuais serão assim a "cola" que integra as ações locais solidárias, onde há produção, com o desejo comunicativo das plataformas digitais. É isso que o pensador Yuk Hui $^{55}$, já mencionado, chamou de solidariedade concreta em oposição à solidariedade abstrata, lançando mão dos conceitos do engenheiro Gilbert Simondon: as redes locais produtivas permitem uma ancoragem técnica aos afetos que circulam nas comunicações pelas mídias sociais.

Mas como a economia solidária poderá se consolidar a partir desse novo paradigma? Podemos considerar as discussões sobre a renda básica universal, antes considerada uma verdadeira questão utópica e estigmatizada como inviável, mas que durante a pandemia ganhou relevância e serviu de base para vários projetos de renda assistencial em muitos países, inclusive no Brasil. Na maioria dos casos, o fornecimento de renda assistencial é visto como alternativa provisória e insustentável a longo prazo.

Numa série de artigos recentes, o professor Renato Dagnino levantou a questão de que a renda básica só se tornará efetiva dentro do paradigma da economia solidária. Dagnino observa que no Brasil (bem como no mundo) adotou-se a fórmula de “emprego e salário" como

\footnotetext{
${ }^{53}$ MANCE, Euclides André. Devemos avançar na organização de circuitos econômicos solidários. IHU notícias, São Leopoldo, 26 jun. 2020. Disponível em http://www.ihu.unisinos.br/78-noticias/600352-devemos-avancarna-organizacao-de-circuitos-economicos-solidarios-entrevista-com-euclides-andre-mance. Acesso em: 09 ago. 2020 .

${ }^{54}$ Um protótipo dessa plataforma é o Fórum Social Mundial das Economias Transformadoras, do qual Mance é um dos organizadores, e que avança a experiência obtida durante o FSM de Porto Alegre para o que tenho chamado de ecologia política.

${ }^{55}$ Cf. Nota 32.
} 
modo de produção econômica. Esse modo adota a lógica da tecnologia convencional (TC) como princípio de eficiência e confia às empresas do mercado a capacidade de gerar empregos, desde que com desoneração tributária e créditos subsidiados. Esse modo tem uma contradição interna, uma vez que a lógica da TC não é gerar emprego, mas poupar trabalho. Como argumentei, a redução de tempo de trabalho necessário a partir da TC não leva ao aumento de tempo livre, mas ao desemprego. Num contexto como esse, a renda básica, defendida mesmo por economistas liberais, teria unicamente a função de subsidiar o consumo e a demanda de empreendedores privados. No final das contas, continuando com a estrutura regressiva tributária (no caso brasileiro), com o controle dos meios de produção nas mãos da iniciativa privada (inclusive com a lógica de inovação sendo usada para desenvolver tecnologias para aumentar a produtividade e poupar empregos), a renda básica significaria realmente a transferência de recursos públicos (dos impostos) para consumidores e destes para o mercado capitalista. Além disso, a renda básica garantiria a reprodução social dessa estrutura iníqua de transferência e geraria uma dilapidação da infraestrutura pública, pois o dinheiro dos impostos seria consumido pela transferência de renda básica e os serviços públicos não poderiam ser mais custeados pelo Estado, levando a pressões pelas privatizações das infraestruturas públicas. É por essa razão que muitos ideólogos liberais defendem a renda básica: porque já entenderam que ela significa apenas transferência de recursos públicos para o setor privado.

A ES pode, no entanto, reverter esse "círculo vicioso" de captura dos recursos pelos mercados privados e transformá-lo num circuito virtuoso. Pois, embora nas suas concepções mais "sociais", a estratégia do "emprego e salário" aja sobre a "distribuição de renda" aos pobres através de políticas compensatórias (como Bolsa Família e Renda Emergencial), a ES já é geração de renda pelos e para os pobres. A lógica da ES é de geração e não de distribuição de renda a partir da acumulação. A ES não supõe uma capitalização dos recursos, mas um fortalecimento das relações de reciprocidade e, com isso, permite através da TS uma perspectiva direta de geração de renda local. Assim, se constrói o círculo virtuoso: a renda básica se torna um "capital social" acumulado que permite alavancar empreendimentos de ES. Com isso, recebedores de renda básica não precisam necessariamente ir aos mercados privados para consumir, podendo usar a renda para adquirir produtos gerados pelas redes cooperativadas ${ }^{56}$.

\footnotetext{
${ }^{56}$ DAGNINO, Renato. A Economia Solidária como eixo da reconstrução nacional. Jornal GGN, [São Paulo], 31 maio 2020. Disponível em: https://jornalggn.com.br/artigos/a-economia-solidaria-como-eixo-da-reconstrucaonacional-por-renato-dagnino/. Acesso em: 09 ago. 2020.
} 
Finalizando, podemos esboçar os seguintes pontos para um projeto de renda básica universal que não signifique nem a fragilização dos serviços públicos de Estado, nem a transferência de recursos públicos para setores privados:

- criar a renda básica universal (RBU) com valor mínimo correspondente ao salário mínimo para todos os trabalhadores não formalizados (sem carteira de trabalho) e para os trabalhadores formalizados com salários abaixo de 5 salários mínimos;

- criação de um fundo público de recursos para o subsídio da renda básica com impostos exclusivamente originados da taxação de capital e da propriedade;

- destinar um percentual desse fundo público de RBU para crédito de inciativas cooperativadas de economia solidária;

- reformar a regulação das cooperativas para torná-las mais simples e acessíveis;

- criar um piso de proteção social com recursos públicos para garantia aos $5 \mathrm{~S}$ da solidariedade: saber, saúde, seguridade, segurança e saneamento;

- criar imposto progressivo de renda sobre salários com diversas alíquotas, impondo cotas altas para super-salários;

- criar um imposto negativo para assalariados com renda superior a 5 salários mínimos com dedução do valor da renda básica do imposto de renda. Com relação aos trabalhadores com renda entre 5 e 6 salários mínimos, torná-los isentos em função dessa dedução;

- para os trabalhadores desempregados, criar um salário-desemprego, no valor do salário mínimo com duração de pelo menos 3 anos, com os benefícios da CLT e um programa de readequação trabalhista;

- criar um programa de ocupação pública para trabalhadores desempregados ou informais, com contratos de prazo definido, de meio-turno, para serviços comunitários de diversas naturezas, com remuneração de salário mínimo mais benefícios trabalhistas;

- para mães de família, com filhos em idade escolar, incluir o Bolsa-Família ao RBU, com valores do mesmo fundo público;

- reduzir a jornada de trabalho de forma escalonada num prazo de 10 anos de 44 para 36 horas.

- incluir na rede pública de educação o programa de letramento digital, bem como nas escolas técnicas, que garanta a soberania digital e torne possível às novas gerações criarem plataformas digitais de acesso aberto. 
: INOVAÇÃo

O grau de acontecimento da pandemia se dá pela constatação de que o projeto de RBU acima esboçado, antes considerado utópico, ou irrealista, agora pode ser discutido em seus termos de eficácia. Trata-se de entender que o que antes era uma anomalia em relação à ortodoxia da teoria econômica clássica torna-se agora um ponto obrigatório de estudo. Não é mais a anomalia que deve ser adequada ao paradigma, mas o paradigma que deve se transformar para suportar a anomalia. $\mathrm{O}$ acontecimento é exatamente a equivocação do desejo para se tornar necessidade. 


\section{REFERÊNCIAS}

AGAMBEN, Giorgio. Uma pergunta. Artigo de Giorgio Agamben. IHU notícias, São Leopoldo, 18 abr. 2020. Disponível em: http://www.ihu.unisinos.br/598071-uma-perguntaartigo-de-giorgio-agamben. Acesso em: 27 jul. 2020

ARRUZZA, C.; BHATTACHARYA, T.; FRASER, Nancy. Feminismo para os 99\%: um Manifesto. São Paulo: Boitempo, 2019.

ASHBY, W. Ross. Introdução à cibernética. São Paulo: Perspectiva, 1970.

BADIOU, Alain. Sobre a situação epidêmica. Blog da Boitempo, São Paulo, 08 abr. 2020. Disponível em: https://blogdaboitempo.com.br/2020/04/08/badiou-sobre-a-situacaoepidemica/ . Acesso em: 27 jul. 2020.

BATESON, Gregory. Steps to an ecology of mind Chicago: University of Chicago Press, 2000.

BENJAMIN, Walter. Obras Escolhidas Volume I: magia e técnica, arte e política. 6. ed. São Paulo: Brasiliense, 1993.

BERARDI, Franco. Bifo Berardi: a frugalidade como pensamento radical. Outras palavras, São Paulo, 16 abr. 2020. Disponível em: https://outraspalavras.net/outrasmidias/bifo-afrugalidade-como-pensamento-radical/. Acesso em: 09 ago. 2020.

BRUNO, Fernanda et al. Tecnopolíticas da Vigilância. São Paulo: Boitempo, 2018.

CAVALCANTI, Clóvis. Concepções da economia ecológica: suas relações com a economia dominante e a economia ambiental. Estudos avançados, São Paulo, v. 24, n. 68, 2010.

Disponível em: https://www.scielo.br/scielo.php?script=sci_arttext\&pid=S0103-40142010000 100007. Acesso em: 03 ago. 2020.

DAGNINO, Renato. A Economia Solidária como eixo da reconstrução nacional. Jornal GGN, [São Paulo], 31 maio 2020. Disponível em: https://jornalggn.com.br/artigos/a-economiasolidaria-como-eixo-da-reconstrucao-nacional-por-renato-dagnino/. Acesso em: 09 ago. 2020.

DAGNINO, Renato. Em direção a uma teoria crítica da tecnologia. In: DAGNINO, Renato (Org.). Tecnologia Social: ferramenta para construir outra sociedade. Campinas: IG/UNICAMP, 2009.

DAGNINO, Renato (Org.). Tecnologia Social: ferramenta para construir outra sociedade. Campinas: IG/UNICAMP, 2009.

DARDOT, P.; LAVAL, C. A nova razão do mundo. São Paulo: Boitempo, 2016.

DAVIS, Mike. "Não vivemos em uma pandemia, mas em uma era de pandemias". Entrevista com Mike Davis. Entrevistadora: Josefina L. Martínez. IHU notícias, São Leopoldo, 2020. Disponível em: http://www.ihu.unisinos.br/78-noticias/601135-nao-vivemos-em-uma-pandem ia-mas-em-uma-era-de-pandemias-entrevista-com-mike-davis. Acesso em: 22 jul. 2020.

DURKHEIM, Emile. Fato social e divisão do trabalho. São Paulo: Ática, 2007. 


\section{ARTIGO}

INOVAÇÃo

ESCOBAR, Pepe. China locked in hybrid war with US. Asia Times, Hong Long, 17 mar. 2020. Disponível em: https://asiatimes.com/2020/03/china-locked-in-hybrid-war-with-us/. Acesso em: 27 jul. 2020.

FEDERICI, Silvia. Calibã e as Bruxas. São Paulo: Elefante, 2017.

FEDERICI, Silvia. Ponto zero da revolução: trabalho doméstico, reprodução e luta feminista. São Paulo: Elefante, 2019.

FEENBERG, Andrew. Between reason and experience: essays in technology and modernity. Massachussets: MIT Press, 2010.

FURTADO, Celso. O mito do desenvolvimento econômico. São Paulo: Paz e Terra (Círculo do Livro), 1974.

GAGO, Verónica. A razão neoliberal. Economias barrocas e pragmática popular. São Paulo: Elefante, 2018.

GREIMAS, Algirdas. Semântica Estrutural. São Paulo: Cultrix, 1973.

HAN, Byung-Chul. O coronavírus de hoje e o mundo de amanhã, segundo o filósofo ByungChul Han. El País Brasil, São Paulo, 22 mar. 2020. Disponível em: https://brasil.elpais.com/id eas/2020-03-22/o-coronavirus-de-hoje-e-o-mundo-de-amanha-segundo-o-filosofo-byungchul-han.html. Acesso em: 28 jul. 2020.

HARARI, Yuval Noah. O mundo depois do coronavírus. IHU notícias, São Leopoldo, 26 mar. 2020. Disponível em: http://www.ihu.unisinos.br/78-noticias/597469-o-mundo-depoisdo-coronavirus-artigo-de-yuval-noah-harari. Acesso em: 28 jul. 2020.

HARAWAY, Donna. J. Manifesto ciborgue: ciência, tecnologia e feminismo-socialista no final do século XX. [S. n.: s. l., 2017]. Disponível em: https://cochabambahotel.noblogs.org/fil es/2017/03/Manifesto_Ciborgue.pdf. Acesso em: 05 ago. 2020.

HARDT, Michael; NEGRI, Antonio. Império. Rio de Janeiro: Record, 2001.

KLEIN, Naomi. Screen New Deal. The Intercept, New York, 8 May 2020. Disponível em: https://theintercept.com/2020/05/08/andrew-cuomo-eric-schmidt-coronavirus-tech-shockdoctrine/. Acesso em: 27 jul. 2020.

HUI, Yuk. Cem anos de crise. São Paulo: N-1 Edições, 2020. Disponível em: https://n-1edico es.org/059. Acesso em: 03 ago. 2020.

INTERNATIONAL MONETARY FUND. Gross debt position: \% of GDP. Washington, DC, 2020. Disponível em: https://www.imf.org/external/datamapper/G_XWDG_G01_GDP_PT@ FM/ADVEC/FM_EMG/FM_LIDC. Acesso em: 06 ago. 2020.

KUHN, Thomas. The structure of scientific revolutions. Chicago: The University of Chicago, 1970.

LATOUR, Bruno. A crise sanitária incita a nos preparar para as mudanças climáticas. IHU Notícias, São Leopoldo, 27 mar. 2020. Disponível em: http://www.ihu.unisinos.br/78- 


\section{ARTIGO}

INOVAÇÃo

noticias/597499-a-crise-sanitaria-incita-a-nos-preparar-para-as-mudancas-climaticas-artigode-bruno-latour. Acesso em: 23 jul. 2020.

LATOUR, Bruno. Onde Aterrar. Rio de Janeiro: Bazar do Tempo, 2020.

MANCE, Euclides André. Constelação Solidarius: as fendas do capitalismo e sua superação sistêmica. Brasília, DF: Ifibe, 2008.

MANCE, Euclides André. Devemos avançar na organização de circuitos econômicos solidários. IHU notícias, São Leopoldo, 26 jun. 2020. Disponível em: http://www.ihu.unisinos .br/78-noticias/600352-devemos-avancar-na-organizacao-de-circuitos-economicos-solidariosentrevista-com-euclides-andre-mance. Acesso em: 09 ago. 2020.

MARCUSE, Herbert. Ideologia da sociedade industrial. Rio de Janeiro: Zahar, 1967.

MATURANA, Humberto; VARELA, Francisco. A árvore do conhecimento. As bases biológicas da compreensão humana. São Paulo: Palas Athena, 2002.

MBEMBE, Achille. Necropolítica. São Paulo: N-1 Edições, 2020.

MOROZOV, Evgney. Big tech: a ascensão dos dados e a morte da política. São Paulo: Ubu, 2018.

NOVAES; DIAS. Contribuições ao marco analítico-conceitual da Tecnologia Social. In: DAGNINO, Renato (Org.). Tecnologia Social: ferramenta para construir outra sociedade. Campinas: IG/UNICAMP, 2009.

POLANYI, Karl. A grande transformação: as origens de nossa época. Rio de Janeiro: Elsevier, 2012.

RANCIÈRE, Jacques. Uma boa oportunidade? São Paulo: N-1 Edições, 2020. Disponível em: https://n-1edicoes.org/039-1. Acesso em: 27 jul. 2020.

ROUVROY, Antoinette; BERNS, Thomas. Governamentalidade algorítmica e perspectivas de emancipação: o díspar como condição de individuação pela relação? Revista EcoPós, Rio de Janeiro, v. 18, n 2, p. 36-56. 2015.

SADIN, Eric. “As tecnologias digitais têm poder de decisão em nossas vidas". Disponível em: http://www.ihu.unisinos.br/601535-as-tecnologias-digitais-tem-poder-de-decisao-em-nossasvidas-entrevista-com-eric-sadin. Acesso em: 06 ago. 2020.

SCHOLES, Robert. Structural fabulation: an essay on fiction of the future. South Bend: University of Notre Dame Press, 1975.

SCHOLZ, Trevor. Cooperativismo de plataforma. São Paulo: Fundação Rosa Luxemburgo; Autonomia Literária; Elefante, 2016.

SHANNON, C. E. A Mathematical Theory of Communication. The Bell System Technical Journal, v. 27, p. 379-423, 623-656, Jul./Oct. 1948. Disponível em: http://people.math.harvar d.edu/ ctm/home/text/others/shannon/entropy/entropy.pdf. Acesso em: 03 ago. 2020. 
SINGER, Paul. Economia solidária versus economia capitalista. Sociedade e Estado, Brasília, DF, v. 16, n. 102, p. 100-112, dez. 2001. Disponível em: https://www.scielo.br/pdf/se/v16n12/v16n1-2a05.pdf . Acesso em: 07 ago. 2020.

SUVIN, Darko. On the poetics of the science fiction genre. College English, v. 34, n. 3, p.-372-382,-Dec.-1972.-Disponível-em:-http://extscifi.weebly.com/uploads/8/9/4/7/8947540/a rticle9.pdf. Acesso em: 03 ago. 2020.

WALLACE, Rob. Big Farms Make Big Flu: Dispatches on Infectious Disease, Agribusiness, and the Nature of Science. New York: Monthly Review Press, 2016. 